\title{
Simulation of trace gases and aerosols over the Indian domain: evaluation of the WRF-Chem model
}

\author{
M. Michael ${ }^{1}$, A. Yadav $^{1}$, S. N. Tripathi ${ }^{1,2}$, V. P. Kanawade ${ }^{1}$, A. Gaur $^{1}$, \\ P. Sadavarte ${ }^{3}$, and C. Venkataraman ${ }^{3}$ \\ ${ }^{1}$ Department of Civil Engineering, Indian Institute of Technology, Kanpur, India \\ ${ }^{2}$ Centre for Environmental Science and Engineering, Indian Institute of Technology, \\ Kanpur, India \\ ${ }^{3}$ Department of Chemical Engineering, Indian Institute of Technology, Mumbai, India
}

Received: 17 December 2013 - Accepted: 20 December 2013 - Published: 16 January 2014

Correspondence to: M. Michael (mary@iitk.ac.in)

Published by Copernicus Publications on behalf of the European Geosciences Union.

\begin{abstract}
The "online" meteorological and chemical transport Weather Research and Forecasting/Chemistry (WRF-Chem) model has been implemented over the Indian subcontinent for three consecutive summers in 2008, 2009 and 2010 to study the aerosol properties over the domain. The model simulated the meteorological parameters, trace gases and particulate matter. Predicted mixing ratios of trace gases (Ozone, carbon monoxide and sulfur dioxide) are compared with ground based observations over Kanpur. Simulated aerosol optical depth are compared with those observed at nine Aerosol Robotic Network stations (AERONET). The simulations show that the aerosol optical 10 depth of the less polluted regions is better simulated compared to that of the locations where the aerosol loading is very high. The vertical profiles of extinction coefficient observed at the Kanpur Micropulse Lidar Network (MPLNET) station is underpredicted by the model by 10 to $50 \%$ for altitudes greater than $1.5 \mathrm{~km}$ and qualitatively simulate the elevated layers of aerosols. The simulated mass concentration of black carbon shows

15 a correlation coefficient of 0.4 with observations. Vertical profiles of black carbon at various locations have also been compared with observations from an aircraft campaign held during pre-monsoon period of 2008 and 2009. This study shows that WRF-Chem model captures many important features of the observed atmospheric composition during the pre-monsoon season in India.
\end{abstract}

\section{Introduction}

Though extensive studies have been carried out to understand the distribution of aerosols in the atmosphere and their direct and indirect effects, the assessment of the aerosol climatic impacts are highly uncertain (Forster et al., 2007). Aerosols, in general, exhibit a large spatial and temporal variability, which influences the spatial distribution of atmospheric radiative effects (Ramanathan et al., 2001; Chung et al., 2005, 2012). The climate effects of atmospheric aerosol particles depend on their distribution 
in the atmosphere along with their optical and microphysical properties. Quantification of the direct radiative effect needs information on the aerosol characteristics on a global scale, which is lacking at present (Anderson et al., 2005; Wild, 2009). Though the understanding of some of the key aerosol properties have been greatly improved

5 by experiments and theoretical studies in recent years, a large uncertainty exist in identifying the differences between the measured and simulated radiative effects (Forster et al., 2007; Myhre, 2009; Myhre et al., 2013; Skeie et al., 2011; Stier et al., 2013).

As the anthropogenic emissions from Asian countries contribute substantially to the global aerosol loading, the study of the distribution of trace gases and aerosols over 10 this region has received increasing attention in recent years (Lawrence and Lelieveld, 2010). Ohara et al. (2007) reported that the total energy consumption in Asian countries have been increasing since 1980, which cause a rapid growth in the emissions. Recent observational and modeling studies have found large spatial and seasonal heterogeneities in the aerosol chemical and physical properties over the Indian re-

15 gion (Ramachandran and Cherian, 2008; Verma et al., 2008; Cherian et al., 2012). Therefore, investigations of aerosol distributions on regional scales and their emission sources are required to probe uncertainties in their atmospheric abundance and climate impacts.

In-situ observations of aerosols have been carried out at a few stations for many 20 years (e.g. Niranjan et al., 1997; Parameswaran et al., 1998; Sikka, 2002; Singh et al., 2004) and there were a few field campaigns, ocean experiments and aircraft observations (Ramanathan et al., 2001; Tripathi et al., 2006; Moorthy et al., 2008; Jaidevi et al., 2011; Kulkarni et al., 2012; Giles et al., 2011) conducted at various regions of India. Nonetheless, there is a dearth of knowledge about the spatial distribution of aerosols over the Indian subcontinent. There are few regional scale modeling studies over the Indian region to understand the distribution of aerosols (Nair et al., 2012; Kumar et al., 2012a, b; Adhikary et al., 2007; Carmichael et al., 2009; Sadavarte et al., 2014). Therefore a chemical transport model, at high spatial resolution, which studies extensively the spatio-temporal distribution of various atmospheric constituents over the Indian

433

domain would further the understanding of the role of aerosols in air quality, radiation budget and weather modification.

In the present work, the Weather Research and Forecast model with online chemistry (WRF-chem) has been implemented over the Indian subcontinent for the pre5 monsoon period of the years 2008, 2009 and 2010. Previously Nair et al. (2012) simulated aerosols over south Asia using the Regional Climate Model (RegCM4) (Giorgi et al., 2012) and found that the modeled aerosol optical depth was not in agreement with observations for regions where the aerosol loading is mainly due to anthropogenic activity. Nair et al. (2012) showed that in the dust dominated regions in the west Asia

10 (averaged over four stations), the monthly AOD showed a correlation coefficient of 0.7 , and those regions which are anthropogenically active (in India and Pakistan), the monthly AOD was underestimated by up to a factor of 2 in the pre-monsoon seasons and up to a factor of 3 in the winter months. The surface concentration and the vertical profiles of black carbon (BC) predicted by the RegCM4 model were underestimated up

15 to a factor of 5 in the winter months and up to a factor of 2 in the summer months, compared to the observations. The authors suggest that the underestimation may be due to the uncertainties in the emission inventory and/or systematic errors in the simulation of atmospheric processes. The diurnal variation of $\mathrm{BC}$ mass concentration was very poorly simulated by the RegCM4 model. Nair et al. (2012) attributed this poor diurnal 20 cycle to the inadequate parameterization of the boundary layer dynamics used in the model. Kumar et al. (2012a) used WRF-chem to simulate the meteorological parameters over South Asia and found that the seasonal averages are simulated by the model reasonably well. Kumar et al. (2012b) simulated trace gases (ozone, carbon monoxide and $\mathrm{NO}_{\mathrm{x}}$ ) and aerosols and reported that the seasonality of $\mathrm{O}_{3}$ and $\mathrm{CO}$ were simulated

25 reasonably well by the model. However, the model showed some differences in $\mathrm{NO}_{\mathrm{x}}$ seasonality, due to the uncertainty in $\mathrm{NO}_{x}$ emission data from fires and satellite retrieval errors in observations. The gas phase chemistry model used in Kumar et al. (2012b) is the Regional Atmospheric Chemical Mechanism (RACM) (Stockwell et al., 1997) and 
the present work uses Regional Acid Deposition Model v2 (RADM2) (Stockwell et al., 1990).

General circulation model studies of aerosols over India (Reddy et al., 2004; Verma et al., 2006, 2008, 2011), using a regional emissions inventory nested in global inven-

5 tories, at spatial resolution of $\sim 80 \mathrm{~km}$ showed significant underestimation of surface concentrations, but satisfactory agreement of AOD. GCM simulations at $\sim 180 \mathrm{~km}$ resolution using updated emissions for 2006 satisfactorily captured spatial and seasonal aerosols distributions and magnitudes of surface concentrations and AOD (Cherian et al., 2012, 2014). These studies made estimates of seasonal radiative forcing and

10 developed an understanding of source and regional contribution to surface and columnar aerosols. Using regional model simulated chemical aerosol fields, corrected with AOD assimilation, in a global model, Chung et al. (2010) estimated a large BC radiative forcing over Asia. In other global models (e.g. Goto et al., 2011; Henriksson et al., 2011), the coarse grid size $2.8^{\circ}$ to $3^{\circ}$ makes the simulations less accurate. Goto et al.

15 (2011) used two BC emission inventories and calculated the spatial radiative forcing, and found that the two simulations showed large differences. Due to the coarse grids used in the global models, the local emissions may be unresolved and can cause error in the radiative forcing calculations (Goto et al., 2011). Henriksson et al. (2011) simulated the seasonal variations of $\mathrm{PM}_{2.5}$ and $\mathrm{AOD}$ over India and found that they are in 20 agreement with the observations qualitatively, but not quantitatively.

In the present work, meteorological parameters, mixing ratio of trace gases, aerosol optical depth, vertical extinction coefficient and BC concentrations, which are simulated using the WRF-chem model are compared with the observations available at various regions of India with emphasis over the Indo-Gangetic Plain (IGP). The intensive opera25 tional period of TIGERZ experiment conducted by the NASA Aerosol Robotic Network (AERONET) project within the IGP occurred during the pre-monsoon period (MayJune) of 2008 (Giles et al., 2011). Aerosol optical, microphysical and absorption properties were studied during this campaign. Semi-permanent and temporary AERONET sites were installed during this period. The aerosol properties were studied over an

435

area covering $50 \mathrm{~km}^{2}$ around Kanpur for a few days and the AODs were observed from the permanent site and two semi-permanent sites during the whole period (Giles et al., 2011). Though a spatial study of the aerosol properties of a part of IGP was done during this campaign, the temporal variation beyond two months could not be captured.

5 Regional weather models can complement such observational campaigns.

The first Continental Tropical Convergence Zone (CTCZ) campaign (Jaidevi et al., 2011) was conducted during the pre-monsoon period of 2008 . The spatial and vertical gradient of various aerosol properties were studied using an airborne platform over the CTCZ region centered at Kanpur during 27-31 May. (Jaidevi et al., 2011). Though

10 the vertical profiles of various aerosol and cloud properties can be studied during such campaigns, a long-term study is not possible. A similar campaign was conducted again during the pre-monsoon period of 2009 (26 June-3 July) to have a comparative study of subsequent pre-monsoon seasons (Jaidevi et al., 2013). Regional models can use the data obtained from such campaigns for validation purposes and then the model 15 can be used for further atmospheric simulations and predictions.

\section{Model description}

The three-dimensional regional model WRF-chem version 3.3 was used in the present study (Grell et al., 2005; Fast et al., 2006). The parameterization schemes and the options used in this study are summarized in Table 1.

20 The domain of the study is set-up over India. The domain encompasses the region $68^{\circ}$ to $99^{\circ} \mathrm{E}$ and $6^{\circ}$ to $37^{\circ} \mathrm{N}$ (Fig. 1). The horizontal grid resolution is $27 \mathrm{~km} \times 27 \mathrm{~km}$ and there are 44 vertical levels with the top layer at $50 \mathrm{hPa}$. The domain of the study with the locations of observations marked is shown in Fig. 1. The static geographical fields such as the terrain height, land-use, vegetation fraction, soil properties, albedo etc. are obtained from the 10 min United States Geological Survey data to the simulation domain by using the geogrid program of the WRF preprocessing system. The initial and lateral boundary conditions for meteorological parameters are obtained from NCEP 
Final analysis (FNL) fields available every six hours at the spatial resolution of $1^{\circ} \times 1^{\circ}$. Simulations were done for the period 1 May to 30 June for 3 consecutive years 2008, 2009 and 2010. With the combined TIGERZ (NASA's AERONET a four-year intensive field campaign started in 2008) and CTCZ campaign (Giles et al., 2011; Jaidevi et al.,

5 2011, 2012), we have an excellent set of aerosol data available for this period over the IGP.

\section{Emissions}

The emissions of $\mathrm{BC}, \mathrm{OC}, \mathrm{PM}_{2.5}$ and sulfur dioxide were available for the model domain for a resolution of $0.25^{\circ} \times 0.25^{\circ}$ for the base year 2006, and are used in the 10 present study (Cherian et al., 2012, 2014). Aerosol and $\mathrm{SO}_{2}$ emissions input to the model (Reddy and Venkataraman, 2002; Venkataraman et al., 2005, 2006) are from a dataset including residential, transport, industry and agricultural residue burning emission sectors. Fossil fuel emissions over the Indian region were projected from base year 1999 (Reddy and Venkataraman, 2002) to the year 2006 using Interna-

15 tional Energy Agency (IEA) fuel consumption data. Emissions from residential cooking with biofuels (Venkataraman et al., 2005) were projected to 2006 using population data. Agricultural residue burning were directly used from Venkataraman et al. (2006), based on a calculation of the amount of residue un-utilized and fraction burned for field clearing. The remaining emissions were obtained from the global emission data sets, 20 which include the REanalysis of the TROpospheric (RETRO) chemical composition and Emission Database for Global Atmospheric Research (EDGAR). These datasets provide global emissions for several greenhouse gases, some precursor gases and particulate matter up to a resolution of $0.5^{\circ} \times 0.5^{\circ}$ grid. As these emissions were based on past years compared to the simulation years, they were projected using various 25 factors provided in Ohara et al. (2007).

\section{Observations}

The simulated results are compared with observed data for meteorological parameters, trace gases and aerosols. The sources of observed data are provided in this section. Meteorological parameters like temperature and relative humidity retrieved from the 5 network of Automatic Weather Stations of Meteorological and Oceanographic Satellite Data Archival Centre (MOSDAC - http://mosdac.gov.in), set-up by Indian Space Research Organization, were used in the present work for the validation of the model. The stations from where the data was used here is presented in Fig. 1. The European Centre for Medium-Range Weather Forecast (ECMWF) operational data on spectral T159

10 resolution (http://www.badc.rl.ac.uk/data/ecmwf-op/) for meteorological fields such as air temperature, relative humidity, wind speed and wind direction at $850 \mathrm{hPa}$ pressure level were also used to study the synoptic meteorological condition over the Indian subcontinent.

Ground based measurements were made for trace gases at Kanpur during the pe-

15 riod of simulation. The surface Ozone was measured by the Ozone analyzer (Model 49i, Thermo Scientific, USA), which works on the principle of the absorption of UV at $253.7 \mathrm{~nm}$ by ozone molecules. Its lowest detectable limit is $0.5 \mathrm{ppbv}$ with a minimum response time of $20 \mathrm{~s}$. Sulphur dioxide was measured using an analyzer (Model 43i, Thermo Scientific, USA) based on an ultraviolet radiation centered at $241 \mathrm{~nm}$, which

20 is the absorption wavelength of $\mathrm{SO}_{2}$ molecules. The minimum detectable limit of the analyzer is $0.5 \mathrm{ppbv}$ for an averaging time of $300 \mathrm{~s}$ and the minimum response time is $320 \mathrm{~s}$. Carbon monoxide measurements were made by CO analyzer (Model 48i, Thermo Scientific, USA). The minimum detectable limit of the analyzer is $0.04 \mathrm{ppm}$ for an averaging time of $30 \mathrm{~s}$ and the minimum response time is $60 \mathrm{~s}$.

Long-term aerosol monitoring has been carried out using a network of sun photometers under the Aerosol Robotic Network (AERONET) program to characterize different types of aerosols at various locations in the world (Smirnov et al., 1996; Eck et al., 1999; Dubovik et al., 2002). For continuous monitoring of aerosols CIMEL radiometers 
are deployed at these stations. These radiometers take measurements of the direct Sun and the diffuse sky radiances within the spectral range 340 to $1020 \mathrm{~nm}$ (Holben et al., 1998). The level 2 quality assured AOD data observed at $550 \mathrm{~nm}$ from various AERONET stations in India were used in the present work. Details about the

5 AERONET stations is provided in Table 2. Aerosol optical depth (AOD) observed at a few AERONET stations like Kanpur (26.51 $\mathrm{N}, 80.23^{\circ} \mathrm{E}$ ) (Singh et al., 2004), Gandhi College (25.87 $\left.\mathrm{N}, 84.13^{\circ} \mathrm{E}\right)$ (Srivastava et al., 2011a; Choudhry et al., 2012), Kharagpur $\left(22.57^{\circ} \mathrm{N}, 88.41^{\circ} \mathrm{E}\right)$, Bareilly $\left(28.39^{\circ} \mathrm{N}, 79.44^{\circ} \mathrm{E}\right.$ ) (Giles et al., 2011), Pantnagar $\left(29.04^{\circ} \mathrm{N}, 79.52^{\circ} \mathrm{E}\right.$ ) (Giles et al., 2012), Nainital $\left(29.36^{\circ} \mathrm{N}, 79.46^{\circ} \mathrm{E}\right)$ (Choudhry

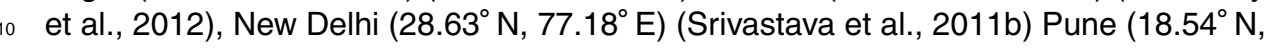
$73.81^{\circ} \mathrm{E}$ ) (Kumar et al., 2011), and Jaipur (26.91 $\left.{ }^{\circ} \mathrm{N}, 75.81^{\circ} \mathrm{E}\right)$ (Gautam et al., 2011), are used for the comparison with the simulated AOD.

Ground based lidar instruments can be used to measure the vertical profiles of atmospheric species, by sending an optical pulse to the atmosphere and studying the

15 backscattered signal. The Micropulse Lidar Network (MPLNET) is a worldwide network of lidars (Welton et al., 2001) co-located with the AERONET sun/sky photometers (Holben et al., 1998). MPLNET uses the micropulse lidar, which is a single wavelength elastic backscatter lidar with wavelengths 523,527 or $532 \mathrm{~nm}$ depending upon the model. The level 2.0 data from the MPLNET site at Kanpur, that operates at the wave-

20 length of $532 \mathrm{~nm}$ has been used in the present study to compare the vertical extinction profiles of aerosols. Due to instrumental constraints the lowest recoverable altitude is $400 \mathrm{~m}$. More details about the data from the MPLNET site at Kanpur can be found in Misra et al. (2012).

An Aethalometer (AE-21-ER, Magee Scientific, USA) has been used to observe BC 25 mass concentration over Kanpur for the whole period of the model simulation. The Aethalometer uses a continuous filtration and optical transmission technique to measure the concentration of $B C$ in near real time and aspirates the ambient air using its inlet tube and its pump. BC mass concentration is estimated by measuring the change in the transmittance of a quartz filter tape, on to which the particle impinge (Hansen

et al., 1984). The uncertainty in BC concentration is 10\% and the specific absorption coefficient used is $16 \mathrm{~m} \mathrm{~g} \mathrm{~m}^{-1}$ (Tripathi et al., 2005). More information about the BC observations at Kanpur is available in many papers (e.g. Tripathi et al., 2005; Shamjad et al., 2012). Vertical profiles of BC mass concentrations at various locations were mea5 sured during the multi-level measurements carried out using the Aethalometer onboard the aircraft Super King Air B200 from the National Remote Sensing Centre during the pre-monsoon period of 2008 and 2009 (Jaidevi et al., 2011, 2012).

\section{Validation of the model}

In this section the simulated results are compared with the observed data. The goal 10 is to assess the ability of the WRF-chem model in simulating meteorological variables, properties of trace gases and aerosols in the atmosphere. The statistical indices used are the correlation coefficient $\left(R^{2}\right)$, root mean square error (RMSE) and the mean bias (MB). Mean bias is defined as

$\mathrm{MB}=\frac{1}{N} \sum_{i=1}^{N}\left(\mathrm{Obs}_{i}-\operatorname{Mod}_{i}\right)$.

15 If $\mathrm{MB}$ is positive the model underpredicts the parameter and vice versa. The best performance of the model is obtained, for high values of $R^{2}$ and low values of RMSE and MB.

Kumar et al. (2012a, b) validated the WRF-chem model over the Indian subcontinent by using the seasonal averages of meteorological parameters and trace gases proper20 ties over the domain. The domain-averaged vertical profiles of meteorological parameters and trace gases were also compared with observations in Kumar et al. (2012a, b) and were found to be in agreement. Though the model can simulate parameters averaged over a large area and long timeframe (e.g. a month, a season or a year), the capability of the model in simulating parameters for every hour and day had to 
be examined. Though monthly and seasonal averages can provide a general assessment of the meteorological situation, simulations at higher spatial and temporal resolution are required to represent small-scale meteorological phenomena. Studies by Qian et al. (2010) and Gustafson et al. (2011) show the importance of using higher 5 spatial and temporal resolution in studying the radiative impact of aerosols. Therefore, in the present work, trace gases and aerosol parameters are simulated every hour or averaged for a day are compared with observations at various locations in India and are then statistically analyzed. However, the meteorological parameters are averaged for two months to see if the model reproduces them realistically, since it is important

10 for the transport and removal of aerosols.

\subsection{Meteorological parameters}

Figure 1a shows the meteorological parameters like air temperature, relative humidity $(\mathrm{RH})$ wind speed and wind direction at $850 \mathrm{hPa}$ simulated by the WRF-chem model and averaged for May and June 2010. Figure $1 \mathrm{~b}$ provides the same parameters for the

15 same period from the ECMWF operation data, and shows that the parameters show a good comparison over the land. Over the Bay of Bengal the simulated $\mathrm{RH}$ is not in a very good agreement with the ECMWF data. Figure 1c and d is for the year 2009 and is similar to that of Fig. $1 \mathrm{a}$ and $\mathrm{b}$ and shows similar agreement between the simulation and the ECMWF data. Figure 1e and $f$ is for the period May-June 2008 and show that

20 the temperature, wind speed and direction are simulated well by the model. But the $\mathrm{RH}$ from the simulation and the ECMWF data are not in good agreement. From Fig. 1a-f, it can also be noted that $\mathrm{RH}$ is simulated less accurately in the coastal area and over the ocean compared with that over land. Kumar et al. (2012a) showed that the water vapor simulated for months March to August by WRF-chem over the peninsular area

25 and over the oceans are not in good agreement with the observations. This divergence could be due to the spatial variability of water vapor associated with the South-Asian monsoon in this region (Kumar et al., 2012a).

To further investigate the simulation of temperature and $\mathrm{RH}$ by the model, the surface data available from MOSDAC has been used. The stations over various parts of the domain have been averaged and then compared with the simulated parameters for the period May-June 2010. Over IGP, there are 20 stations within an area of $26^{\circ}$

5 to $31^{\circ} \mathrm{N}$ and $74^{\circ}$ to $80^{\circ} \mathrm{E}$. The hourly data of temperature and $\mathrm{RH}$ from these stations are averaged for May and June 2010 and compared with those simulated for these grids, which are shown in Fig. $2 a$ and d. Considering the fact that these are hourly data which have been compared, the correlation coefficients of 0.77 and 0.64 can be considered good. The mean bias $\left(-5.13^{\circ} \mathrm{C}\right.$ and $\left.22.8 \%\right)$ shows that the temperature

10 is overpredicted and the $\mathrm{RH}$ is underpredicted by the model in this region. In a similar manner the hourly data from 190 stations in the central part of India $\left(15^{\circ}\right.$ to $25^{\circ} \mathrm{N}$ and $72^{\circ}$ to $81^{\circ} \mathrm{E}$ ) have been shown as scatter plots in Fig. $2 \mathrm{~b}$ and e. The correlation coefficients are 0.82 and 0.76 , respectively for temperature and $\mathrm{RH}$. The mean bias $\left(-2.65^{\circ} \mathrm{C}\right.$ and $\left.13.4 \%\right)$ shows that the model overpredicts the temperature and underpredicts the $\mathrm{RH}$. Figure $2 \mathrm{c}$ and f shows the scatter plots of temperature and $\mathrm{RH}$ from the southern part (coastal area) of India. Stations are located within the area $8^{\circ}$ to $13^{\circ} \mathrm{N}$ and $74^{\circ}$ to $80^{\circ} \mathrm{E}$. Data from about 151 stations are used to make the comparison with the simulated result. The mean bias calculated are $4.9^{\circ} \mathrm{C}$ and $-13.6 \%$, respectively for temperature and $\mathrm{RH}$. Unlike IGP and central India, the temperature is underpredicted

20 and $\mathrm{RH}$ is overpredicted in the coastal area. Also the correlation coefficients $(0.5$ and 0.52 , respectively) are not as good as those at IGP and central India, in line with the comparison of the data with ECMWF (Fig. 1b). As it appeared, there exist an autocorrelation in the simulated data. We have performed the Cochrane-Orcutt Procedure to correct data for autocorrelation errors before calculating correlation coefficients be-

25 tween observed and simulated data. Note that, Cochrane-Orcutt Procedure does not remove autocorrelated data points, instead adjust a linear model for autocorrelation in the error terms (i.e. linear fit line). 


\subsection{Trace gases}

During the pre-monsoon period of 2010 ozone, carbon monoxide and sulfur dioxide were observed hourly at Kanpur using instruments mentioned in Sect. 4. Long-term measurements of trace gases have begun at Kanpur by the end of 2009 and so the

5 mixing ratio of the trace gases during the pre-monsoon seasons of 2008 and 2009 could not be studied at Kanpur.

\subsubsection{Ozone}

Surface ozone is produced by photochemistry involving pollutants released from various anthropogenic activities. Surface ozone does not have direct natural sources, but

10 it is produced mainly from its precursors emitted by anthropogenic activities. An ozone molecule is produced by the recombination of atomic oxygen with an oxygen molecule. In the troposphere, the required atomic oxygen is produced by the photodissociation of $\mathrm{NO}_{2}$, which is emitted mainly by fossil fuel combustion (Lal et al., 2000; Purkait et al., 2009). Figure 4 shows the daily averages of the mixing ratio of ozone at Kanpur for the 15 period May-June 2010. The observed mixing ratio of ozone is $38.63 \pm 17.74 \mathrm{ppbv}$ and the simulated mean is $51.06 \pm 22.72 \mathrm{ppbv}$. During cloudy-rainy days, due to the nonavailability of sufficient solar radiation and washout of pollutants the photochemical ozone production decreases. Therefore during monsoon months the ozone concentration usually decreases (Lal et al., 2000). The observed data shows a mean ozone 20 mixing ratio of $43.81 \pm 18.83$ ppbv during May and $33.31 \pm 14.77$ ppbv during June. This is correlated with the monsoon onset about mid June at Kanpur. The simulated mixing ratios during May and June are $53.47 \pm 26.34$ ppbv and $48.56 \pm 17.92$ ppbv, respectively. While the observation shows a $20 \%$ reduction in the ozone concentration from May to June, the simulation only shows a $10 \%$ reduction. i.e. after mid June (after the onset

25 of monsoon) the observed mixing ratio is $\sim 30$ ppbv or less, which is not simulated well by the model. The MB, RMSE and correlation coefficient are provided in Table 2 . In the present work a simplified parameterization of the wet scavenging scheme has been

443

used and it underestimates the wet removal of the pollutants (Tuccella et al., 2012) and therefore the reduction in the concentration of ozone from May to June is not simulated well by the model.

The ozone concentrations have a characteristic diurnal variation. The ozone con5 centration is usually minimum during the night-time and it starts to increase gradually after sunrise, attains a maximum value around noon time and then it starts to decrease between 1700 to 2000 and gradually reaches a minimum. During the day the maximum ozone production is due to the photolysis of $\mathrm{NO}_{2}$. Ozone is also produced in the atmosphere from VOCs and the low value of concentration in the night is mainly due to

10 the absence of photo-chemical reactions. Ozone is removed from the atmosphere by its reaction with $\mathrm{NO}$ producing $\mathrm{NO}_{2}$ and $\mathrm{O}_{2}$. Additionally, ozone oxidizes $\mathrm{NO}_{2}$ during the night-time producing the nitrate radical $\left(\mathrm{NO}_{3}\right)$. The observed and simulated diurnal variation of the mixing ratio of ozone at Kanpur is provided in Fig. 5. Though the observed and simulated mixing ratios are well within the error bars, the simulated values

15 show a positive bias. While the simulated nighttime concentrations are within $10 \%$ of the observed values, the simulated daytime concentrations are overpredicted by about $30 \%$.

\subsubsection{Carbon monoxide}

Carbon monoxide is mainly produced from vehicular exhaust in the urban areas and 20 from biomass burning in the rural areas. Figure 6 shows the mixing ratio of $\mathrm{CO}$ averaged daily for the period May-June 2010 at Kanpur. The observed mean CO mixing ratio is $0.56 \pm 0.26 \mathrm{ppmv}$ and the simulated mixing ratio is $0.42 \pm 0.29 \mathrm{ppmv}$. Though the $\mathrm{CO}$ concentration is not usually affected by the monsoon onset, the simulated mixing ratio shows a small concentration of $\sim 0.2 \mathrm{ppmv}$ for the period from 21-30 June. The 25 simulated monthly average for May $(0.53 \pm 0.33 \mathrm{ppmv})$ is in very good agreement with that of the observation $(0.55 \pm 0.26 \mathrm{ppmv})$, but that of June $(0.29 \pm 0.18$ (simulated) and $0.57 \pm 0.25$ (observed)) is underpredicted by about $50 \%$. The over-prediction in June is mainly due to the simpler parameterization used for the wet scavenging scheme, 
which leads to a low bias in wet removal. The MB, RMSE and correlation coefficient are provided in Table 2.

\subsubsection{Sulfur dioxide}

Sulfur dioxide is mainly produced in the atmosphere by fossil fuel combustion at power 5 plants and other industrial facilities. It is also present in vehicle emissions due to the fuel combustion. Figure 7 shows the mixing ratio of $\mathrm{SO}_{2}$ at Kanpur averaged daily for the pre-monsoon period of 2010. The average simulated and observed $\mathrm{SO}_{2}$ mixing ratios are $3.21 \pm 3.72 \mathrm{ppbv}$ and $1.76 \pm 3.11$, respectively, indicating a model overprediction. This could result from a low bias in rate of sulfate formation or low deposi-

10 tion/scavenging of $\mathrm{SO}_{2}$. Sulfate was satisfactorily simulated during this period. Both the simulated and the observed data show that the month of May $(4.27 \pm 4.18$ (simulated), $2.64 \pm 3.83$ (observed)) shows a higher mixing ratio compared to that of June $(2.12 \pm 2.79$ (simulated), $0.86 \pm 1.71$ (observed)). The observed and simulated mixing ratios decrease about $30 \%$ and $50 \%$ from May to June. The MB, RMSE and correlation 15 coefficient are provided in Table 2.

\subsection{Aerosols}

The daily Aerosol Optical Depth (AOD) at various AERONET stations within the domain during the simulation period are presented in this section. The extinction coefficient at $550 \mathrm{~nm}$ simulated using the model was used to calculate the AOD by integrating it

20 over altitude. As mentioned earlier the level 2.0 AERONET data from Kanpur, Gandhi College, Kharagpur, Bareilly, Pantnagar, Nainital, Delhi, Pune, and Jaipur, are used in the study. The AOD data from Kanpur, Nainital, and Pune are available for all the three pre-monsoon seasons considered in the present work. The AOD data at the Jaipur AERONET station is available for 2009 and 2010. At Bareilly the AOD data are 25 available for the pre-monsoon season of 2008 and at Pantnagar the data are available

for 2008 and 2009. At Gandhi College, Delhi and Kharagpur the AOD data are available for 2009 only.

\subsubsection{Aerosol Optical Depth}

Figure 8 shows the simulated AOD along with the observed AOD at Kanpur, where

5 most of the aerosols are produced by anthropogenic activity. During the pre-monsoon season, an influence of dust loading is observed in the coarse mode at Kanpur (Gautam et al., 2011). Figure 8 a-c shows the AODs during three consecutive pre-monsoon seasons, May-June 2008, 2009 and 2010, respectively, at Kanpur. The daily mean observed AODs range from 0.4 to 1.4 , whereas the simulated AODs vary in the range

$10 \quad 0.2$ to 1.4. Though, most of the days, the simulated and observed AOD are within the error bars, the simulation has a tendency to slightly under-estimate the AODs. The underprediction in simulated AOD is mainly due to underpredicted dust concentration on corresponding days. For days when the AOD is very high (greater than 0.8 ), it has been seen from the AERONET data that the coarse mode AOD is contributing more

15 compared to that of the fine mode to the total AOD. From CALIPSO data (whenever available for those days with high AOD), it is observed that elevated layers of dust is present up to an altitude of $5 \mathrm{~km}$. HYSPLIT analysis, using wind-fields from Global Data Assimilation System, shows transported air masses from middle-eastern region during this period. Moreover, Bian et al. (2011) showed that the dust scheme used with 20 the MADE/SORGAM aerosol scheme in WRF-chem does not simulate the transport of dust very well. Therefore, it is indicated that WRF-chem simulates the locally generated dust very well, but transported dust may not be represented very well. This could be a reason for the underprediction of AOD during certain days. Table 3 shows the simulated and observed averages and standard deviations for the pre-monsoon months of 25 each year. The MB, RMSE and correlation coefficient are provided in Table 4.

Jaipur is an urban location in the north-western India near the western edge of Thar desert. It is a dust dominated location when the dust influx is not only from the Thar desert, but also from the long-range transport from the Middle-Eastern peninsular 
regions (Gautam et al., 2011). Figure 9a and $b$ shows the simulated and observed AOD at Jaipur for the months of May and June during years 2009 and 2010, respectively. There is no data available during the pre-monsoon season of 2008 from Jaipur station. The observed data shows that the AOD ranges from 0.2 to 1.2 and the simulated AOD

5 is well within the range. The HYSPLIT backward trajectory model shows that, at Jaipur the air mass arrives from the middle-eastern peninsular region on those days when the $A O D$ is very high (greater than 0.8 ). For those days when the AOD is about 0.6 or less the backward trajectory analysis shows locally generated particles. This shows again that the WRF-model simulates the locally generated aerosol concentration quite well.

10 Table 3 presents the average AOD values, and Table 4 provides the MB, RMSE and correlation coefficient.

Nainital is a high altitude region situated at the foothills of Himalayas with relatively clean air compared to other locations in the domain, like Kanpur. Figure 10 presents the simulated and observed AOD at Nainital. The AOD is usually less than 0.6 (for 15 more than $90 \%$ of the simulation days). Occasionally, the AOD is greater than 0.8 . The simulation shows similar trend whenever observed data is available. Table 3 shows the agreement in the average values during the months of May and June for 2008-2010. The MB, RMSE and correlation coefficient are provided in Table 4.

Figure 11 shows the daily AODs at Gandhi College, Kharagpur, which is an extension of the Kolkata AERONET station and New Delhi. Gandhi College is a rural site in the IGP about $466 \mathrm{~km}$ east of Kanpur. Two rivers, Ganga and Ghaghra frequently flood the area making it highly fertile and most of the land is used for cultivation (Choudhry et al., 2012). Also the use of biofuels mainly contribute to the aerosol formation at Gandhi College (Habib et al., 2006). Gandhi College shows higher AOD than at Kanpur as the sources or aerosols in both the sites differ (Choudhry et al., 2012; Srivastava et al., 2012a). The daily averaged observed AOD at Gandhi College during May-June 2009 vary from 0.3 to 1.5 and the simulated AODs vary from 0.1 to 1 . Dust transport occurs in these months over the whole of north India, but may not be represented adequately by the model. Kharagpur is a small town located about $80 \mathrm{~km}$ inland of the west coast

of the Bay of Bengal. Kharagpur is situated almost at the eastern end of IGP. The simulated AODs at Kharagpur is in good agreement with the observations for almost half of the simulation period and underpredicted for the rest of the period. New Delhi is located at the western part of IGP and is one of the most polluted and industrialized 5 cities of Asia with extensive dust loading from the nearby Thar desert during the premonsoon period (Pandithurai et al., 2008; Srivastava et al., 2011b). There are only 8 days of data available for the month of June and are in good agreement with the simulation. During May, the simulated AODs are slightly lower than the observed values for a few days as the model does not pick up the transported dust from the Than desert.

10 The average AOD from all three stations for May-June 2009 is provided in Table 3. The level 2.0 AOD data for these three stations were available only for the year 2009 and therefore the period May-June 2009 has been given in Fig. 11. The MB, RMSE and correlation coefficient are provided in Table 4.

Figure 12 presents the simulated and observed AOD at Bareilly and Pantnagar 15 AERONET stations. These are semi-permanent AERONET sites north of Kanpur near the Himalayan foothills to study the latitudinal variation of aerosols over IGP (Giles et al., 2011). At Bareilly, the AOD data are available only for the year 2008 and at Pantnagar, the data are available for 2008 and 2009. At both the stations during May and June 2008, the observed daily AODs are very similar. The simulated AODs for the

20 same period show a similar trend at both the stations. The simulated AODs are underpredicted for a few days during the simulation period. AERONET data shows higher contribution from coarse mode particles during 25-28 June 2009 at Pantnagar. The back trajectory analysis using the HYSPLIT model shows transported air mass from west Asia desert regions to the northwest. The underprediction of AOD during this pe-

25 riod by the model may be attributed to the poor representation of transported dust in the model. Similarly, the high AOD during 12-13 June 2008 at Pantnagar, which is underpredicted by the model, is also due to the coarse mode contribution, which is also due to the transported dust from desert regions to the west. The observed and simulated 
average AODs are provided in Table 3. The MB, RMSE and correlation coefficient are provided in Table 4.

Pune is an urban station situated about $100 \mathrm{~km}$ inland of the west coast of India. The type of aerosols present at this location are a mixture of dust-like particles and that of

5 anthropogenic origin (Kumar et al., 2011) and the aerosol loading is less compared to the IGP. Figure 13a-c shows the simulated and observed AOD at Pune for the premonsoon periods of 2008, 2009 and 2010, respectively. The observed AODs are less than 0.6 for most of the simulation period and the calculated AODs show a similar trend. As the AOD at $500 \mathrm{~nm}$ is not measured at the AERONET station at Pune, the

10 simulated $A O D$ at $550 \mathrm{~nm}$ has been compared with the measured AOD at $675 \mathrm{~nm}$. The average AODs for May and June 2008, 2009 and 2010 are given in Table 3. The MB, RMSE and correlation coefficient are provided in Table 4.

\subsubsection{Vertical profiles of extinction coefficient}

The monthly averaged extinction coefficients are provided in Fig. 14a-d for the months 15 May, June 2009, May and June 2010. For altitudes less than $1.5 \mathrm{~km}$ the extinction coefficients are not simulated well by the model. Misra et al. (2012) reported that higher extinction for altitudes $2-4 \mathrm{~km}$ was observed from April to June period, resulting from the elevated layers of aerosols. The simulated extinction coefficient is within the error bars of the observed data for altitudes greater than $2 \mathrm{~km}$.

\section{5.3.3 Black Carbon}

Figure $15 \mathrm{a}$ and $\mathrm{b}$ show the $\mathrm{BC}$ mass concentration observed at Kanpur during every hour along with the simulated values using the model for May and June 2009 and 2010. It is clear that the simulated BC concentration is in good agreement with the observations during both the years. For May-June 2009, the observed and simulated averages 25 of $\mathrm{BC}$ mass concentrations are 1.54 and $1.33 \mathrm{\mu g} \mathrm{mm}^{-3}$, respectively. For 2010 , the averages are found to be 2.07 and $1.33 \mu \mathrm{gmm}^{-3}$, respectively. The MB, RMSE and

the correlation coefficient are calculated as $0.45,0.92$ and 0.40 , respectively. The BC mass concentration shows a characteristic diurnal variation and to find out how the model simulates the same, the monthly averaged diurnal variation has been presented in Fig. 16a-d. The night-time peak and the afternoon low in the BC mass concentration 5 is simulated very well by the model. Nair et al. (2012) recently simulated the diurnal variation of $\mathrm{BC}$ mass concentration using RegCM model at Thiruvananthapuram and Kharagpur and the poor agreement with observations was attributed to an unsatisfactory boundary layer parameterization. Misenis et al. (2010) studied different boundary layer parameterizations used in WRF-chem and found that the one used in the present

10 work (MYJ scheme) reproduces the meteorological parameters and trace gases mixing ratios and their diurnal pattern very well, over Houston-Galveston area in Texas, USA, in summer. However, Misenis et al. (2010) reported that the MYJ scheme shows deficiencies in capturing the small-scale phenomena in coastal area where land-sea interactions are to be included. Shin et al. (2011) also studied different boundary layer

15 schemes in WRF-chem and suggested that all schemes, including the MYJ scheme worked well during unstable atmospheric conditions, but showed small uncertainties in representing surface variables especially under stable conditions. In addition, the regional emissions inventory provides more realistic $B C$ emissions over the domain. Therefore, this study has been able to capture the characteristic diurnal variation of $B C$ 20 mass concentration using a regional model, over the Indian domain.

Vertical profiles of BC mass concentrations were observed during the multi-level measurements carried out during the pre-monsoon season of 2009 using instruments onboard National Remote Sensing Centre Beachcraft (Jai Devi et al., 2011, 2014). Figure 17a shows the vertical profiles at Kanpur observed on 29 June 2009 during 14:30 to

25 17:20 LT along with the simulated vertical profile for the same period. Though both the profiles show similar trends up to an altitude of $3 \mathrm{~km}$, they start diverging for altitudes greater than $3 \mathrm{~km}$. One vertical profile each were observed on 2 July morning (11:00 to 12:40 LT) and afternoon (1430 to 1510 local time). The simulated BC mass concentrations for the same time period have also been shown in Fig. 17a. The observed and 
simulated profiles for the morning of 2 July 2009 are in agreement for altitudes less than $4 \mathrm{~km}$ and the profiles start to diverge for altitudes greater than $4 \mathrm{~km}$. During the observations of 2 July afternoon there is only one observation each between 2 to $3 \mathrm{~km}$ and 3 to $4 \mathrm{~km}$ and therefore there are no error bars for these two points. The sharp 5 decrease at $3 \mathrm{~km}$ is not seen in the simulated profile.

Figure 17b shows the vertical profiles of $\mathrm{BC}$ mass concentration observed at Nainital on 29 June 2009 (09:20-12:30 LT). The simulated profile failed to reproduce the elevated layers in the observed profile. Figure $17 \mathrm{c}$ shows simulated and observed vertical profiles at Jaipur for 3 July 2009 during 13:00 to 15:00 LT. The profiles are in very good

10 agreement for altitudes less than $2.5 \mathrm{~km}$ and they start to diverge for altitudes greater than $3 \mathrm{~km}$. There are no observations available for altitudes greater than $4 \mathrm{~km}$ at Jaipur.

\section{Conclusions}

The performance of the WRF-chem model in simulating the aerosol properties over the Indian domain is evaluated in the present work. The pre-monsoon months (May-

15 June) of $3 \mathrm{yr} 2008$ to 2010 were selected for the present validation work. In general, monsoon arrives at the southern coast of India by the last week of May every year and it reaches the northern India by mid June. i.e. May-June is a transition period of two different seasons in the northern India. This work gives more emphasis on the IGP, which is located in the northern part of India, and is surrounded by Himalayas to the 20 north, moderate Hills to the south, Thar desert and Arabian sea in the west and Bay of Bengal in the east. There were 7 AERONET stations operating in this region during the period of study. Two more AERONET stations (Jaipur and Pune) were also operational during the period of study. The data (mainly, vertical BC mass concentration) collected during the aircraft campaign in the IGP during the pre-monsoon period of 2008 and 252009 , are used in the study for the validation of the model.

The AOD simulated at stations in the IGP (Kanpur, Kharagpur, New Delhi, Bareilly, Pantnagar, Gandhi College) show almost $40 \%$ underestimation compared to the

observed values. The high-altitude station (Nainital), which is cleaner than those stations in the IGP show a good agreement in general with the observations. The results from the urban station (Pune) which is located at the southern part of India and less polluted than the stations in IGP also show good agreement with observed AOD. The 5 simulated $A O D$ in the dust dominated region (Jaipur) is within $20 \%$ of the observed data. Therefore the aerosol properties in the less polluted locations are better simulated by the model compared to that of the highly polluted regions. It is shown that the transported dust is not captured well by the model. The profiles of extinction coefficient at Kanpur show that the model is able to qualitatively simulate the elevated 10 layers of aerosols during the pre-monsoon seasons as observed by the Micropulse Lidar. The BC mass concentration observed at Kanpur is simulated well by the model. The characteristic diurnal variations of $\mathrm{BC}$ are very well captured by the model. The vertical profiles of $\mathrm{BC}$ mass concentration at Kanpur are well within the range of observed values. The good agreement of $B C$ mass concentration between the model and the observations may be due to the improved inventory used, which is better than the global inventory for other emissions. Since the vertical profiles are available only for a few days, the comparison was limited. Nevertheless, the model shows good agreement for altitudes less than $2 \mathrm{~km}$. The present study shows that the WRF-chem model can be used to understand the various atmospheric processes in the Indian domain.

20 Acknowledgements. A part of this work is supported by a grant from Changing Water Cycle program jointly co-ordinated by Ministry of Earth Sciences, India and Natural Environmental Research Council, UK. The authors acknowledge the AWS data received from Meteorological and Oceanographic Satellite Data Archival Centre (MOSDAC). We acknowledge the use of ECMWF operational reanalysis data from the British Atmospheric Data Centre (BADC), which

25 is part of the NERC National Centre for Atmospheric Science (NCAS). We gratefully acknowledge the data provided by the AERONET network, and appreciate the PIs and the operators of the stations at Delhi, Kanpur, Gandhi College, Nainital, Pantnagar, Bareilly, Kharagpur, Jaipur and Pune. MM acknowledges support through the DST-Fast Track Fellowship. 


\section{References}

Ackermann, I. J., Hass, H., Memmesheimer, M., Ebel, A., Binkowski, F. S., and Shankar, U.: Modal aerosol dynamics model for Europe: development and first applications, Atmos. Environ., 32, 2981-2999, doi:10.1016/S1352-2310(98)00006-5, 1998.

5 Adhikary, B., Carmichael, G. R., Tang, Y., Leung, L. R., Qian, Y., Schauer, J. J., Stone, E. A., Ramanathan, V., and Ramana, M. V.: Characterization of the seasonal cycle of south Asian aerosols: a regional-scale modeling analysis, J. Geophys. Res., 112, D22S22, doi:10.1029/2006JD008143, 2007.

Anderson, T. L., Charlson, R. J., Bellouin, N., Boucher, O., Chin, M., Christopher, S. A., Hay-

10 wood, J., Kaufman, Y. J., Kinne, S., Ogren, J. A., Remer, L. A., Takemura, T., Tanré, D., Torres, O., Trepte, C. R., Wielicki, B. A., Winker, D. M., and Yu, H.: An "A-Train" strategy for quantifying direct climate forcing by anthropogenic aerosols, B. Am. Meteorol. Soc., 86, 1795-1809, doi:10.1175/BAMS-86-12-1795, 2005.

Bian, H., Tie, X., Cao, J., Ying, Z., Han, S., and Xue, Y.: Analysis of a severe dust storm event over China: application of the WRF-Dust model, Aerosol Air Qual. Res., 11, 419-428, doi:10.4209/aaqr.2011.04.0053, 2011.

Carmichael, G. A., Adhikary, B., Kulkarni, S., D’Allura, A., and Tang, Y.: Asian aerosols: current and year 2030 distributions and implications to human health and regional climate change, Environ. Sci. Technol., 43, 5811-5817, doi:10.1021/es8036803, 2009.

20 Chen, F. and Dudhia, J.: Coupling an advanced land surface-hydrology model with the Penn State-NCAR MM5 modeling system - Part 1: Model implementation and sensitivity, Mon. Weather Rev., 129, 569-585, doi:10.1175/1520-0493(2001)129<0569:CAALSH>2.0.CO;2, 2001

Cherian, R., Venkataraman, C., Ramachandran, S., Quaas, J., and Kedia, S.: Examination of aerosol distributions and radiative effects over the Bay of Bengal and the Arabian Sea region during ICARB using satellite data and a general circulation model, Atmos. Chem. Phys., 12, 1287-1305, doi:10.5194/acp-12-1287-2012, 2012.

Cherian, R., Venkataraman, C., Quaas, J., and Ramachandran, S.: General circulation model (ECHAM5-HAM) studies of aerosol extinction, atmospheric heating and precipitation patterns over India, J. Geophys. Res., submitted, 2014.

Chou, M. D., Suarez, M. J., Ho, C. H., Yan, M. M. H., and Lee, K. T.: Parameterizations for cloud overlapping and shortwave single-scattering properties for use in gen-

eral circulation and cloud ensemble models, J. Climate, 11, 202-214, doi:10.1175/15200442(1998)011<0202:PFCOAS>2.0.CO;2, 1998.

Choudhry, P., Misra, A., and Tripathi, S. N.: Study of MODIS derived AOD at three different locations in the Indo Gangetic Plain: Kanpur, Gandhi College and Nainital, Ann. Geophys., 30, 1479-1493, doi:10.5194/angeo-30-1479-2012, 2012.

Chung, C. E., Ramanathan, V., Kim, D., and Podgorny, I. A.: Global anthropogenic aerosol direct forcing derived from satellite and ground-based observations, J. Geophys. Res., 110, D24207, doi:10.1029/2005JD006356, 2005.

Chung, C. E., Ramanathan, V., Carmichael, G., Kulkarni, S., Tang, Y., Adhikary, B., Leung, L. R., and Qian, Y.: Anthropogenic aerosol radiative forcing in Asia derived from regional models with atmospheric and aerosol data assimilation, Atmos. Chem. Phys., 10, 6007-6024, doi:10.5194/acp-10-6007-2010, 2010.

Chung, C. E., Ramanathan, V., and Decremer, D.: Observationally constrained estimates of carbonaceous aerosol radiative forcing, P. Natl. Acad. Sci. USA, 109, 11624-11629, doi:10.1073/pnas.1203707109, 2012.

Dubovik, O., Holben, B. N., Eck, T. F., Smirnov, A., Kaufman, Y. J., King, M. D., Tanre, D., and Slutsker, I.: Variability of absorption and optical properties of key aerosol types observed in worldwide locations, J. Atmos. Sci., 59, 590-608, 2002.

Eck, T. F., Holben, B. N., Reid, J. S., Dubovik, O., Smirnov, A., O'Neill, N. T., Slutsker, I., and Kinne, S.: Wavelength dependence of the optical depth of biomass burning, urban and desert dust aerosol, J. Geophys. Res., 104, 31333-31350, doi:10.1029/1999JD900923, 1999.

Fast, J. D., Gustafson Jr., W. I., Easter, R. C., Zaveri, R. A., Barnard, J. C., Chapman, E. G., Grell, G. A., and Peckham, S. E.: Evolution of ozone particulates, and aerosol direct radiative forcing in the vicinity of Houston using a fully couples meterorology-chemistry-aerosol model, J. Geophys. Res., 111, D21305, doi:10.1029/2005JD006721, 2006.

Forster, P., Ramaswamy, V., Artaxo, P., Berntsen, T., Betts, R., Fahey, D. W., Haywood, J., Lean, J., Lowe, D.C., Myhre, G., Nganga, J., Prinn, R., Raga, G., Schulz, M., and Van Dorland, R.: Changes in atmospheric constituents and in radiative forcing, in: Climate Change 2007: The Physical Science Basis, Contribution of Working Group I to the Fourth Assessment Report of

30 the Intergovernmental Panel on Climate Change, edited by: Solomon, S., Qin, D., Manning, M., Chen, Z., Marquis, M., Averyt, K. B., Tignor, M., and Miller, H. L., Cambridge University Press, UK and USA, 129-234, 2007. 
Francis, P. A. and Gadgil, S.: Towards understanding the unusual Indian monsoon in 2009, J. Earth Syst. Sci., 119, 397-415, doi:10.1007/s12040-010-0033-6, 2010

Gautam, R., Hsu, N. C., Tsay, S. C., Lau, K. M., Holben, B., Bell, S., Smirnov, A., Li, C., Hansell, R., Ji, Q., Payra, S., Aryal, D., Kayastha, R., and Kim, K. M.: Accumulation of aerosols over the Indo-Gangetic plains and southern slopes of the Himalayas: distribution, properties and radiative effects during the 2009 pre-monsoon season, Atmos. Chem. Phys., 11, 12841-12863, doi:10.5194/acp-11-12841-2011, 2011.

Giles, D. M., Holben, B. N., Tripathi, S. N., Eck, T. F., Newcomb, W. W., Slutsker, I., Dickerson, R. R., Thompson, A. M., Mattoo, S., Wang, S. H., Singh, R. P., Sinyuk, A., and Schafer, J. S.: Aerosol properties over the IndoGangetic Plain: a mesoscale perspective from the TIGERZ experiment, J. Geophys. Res., 116, D18203, doi:10.1029/2011JD015809, 2011.

Goto, D., Takemura, T., Nakajima, T., and Badarinath, K. V. S.: Global aerosol modelderived black carbon concentration and single scattering albedo over Indian region and its comparison with ground observations, Atmos. Environ., 45, 3277-3285, doi:10.1016/j.atmosenv.2011.03.037, 2011.

Grell, G. A. and Devenyi, D.: A generalized approach to parameterizing convection combining ensemble and data assimilation techniques, Geophys. Res. Lett., 29, 1693, doi:10.1029/2002GL015311, 2002.

Grell, G. A., Peckham, S. E., Schmitz, R., McKeen, S. A., Frost, G., Skamarock, W. C., and

20 Eder, B.: Fully coupled online chemistry within WRF model, Atmos. Environ., 39, 6957-6975, doi:10.1016/j.atmosenv.2005.04.027, 2005.

Gustafson, W. I., Qian, Y., and Fast, J. D.: Downscaling aerosols and the impact of neglected subgrid processes on direct aerosol radiative forcing for a representative global climate model grid spacing, J. Geophys. Res., 116, D13303, doi:10.1029/2010JD015480, 2011.

25 Habib, G., Venkataraman, C., Chiapello, I., Ramachandran, S., Boucher, O., and Reddy, M. S.: Seasonal and interannual variability in absorbing aerosols over India derived from TOMS: relationship to regional meteorology and emissions, Atmos. Environ., 40, 1909-1921, doi:10.1016/j.atmosenv.2005.07.077, 2006.

Hansen, A. D. A., Rosen, H., and Novakov, T.: The aethalometer - an instrument for the realtime measurement of optical absorption by aerosol particles, Sci. Total Environ., 36, 191196, doi:10.1016/0048-9697(84)90265-1, 1984.

Henriksson, S. V., Laaksonen, A., Kerminen, V.-M., Raisanen, P., Jarvinen, H., Sundstrom, A.M., and De Leeuw, G.: Spatial distributions and seasonal cycles of aerosols in In-

455

dia and China seen in global climate-aerosol model, Atmos. Environ., 11, 7975-7990, doi:10.5194/acp-11-7975-2011, 2011.

Holben, B. N., Eck, T. F., Slutsker, I., Tanré, D., Buis, J. P., Setzer, A., Vermote, E., Reagan, J. A., Kaufman, Y. J., Nakajima, T., Lavenu, F., Jankowiak, I., and Smirnov, A.: AERONET: a federated instrument network and data archive for aerosol characterization, Remote Sens. Environ., 66, 1-16, 1998.

Jai Devi, J., Tripathi, S. N., Gupta, T., Singh, B. N., Gopalakrishnan, V., and Dey, S.: Observation-based 3-D view of aerosol radiative properties over Indian Continental Tropical Convergence Zone: implications to regional climate, Tellus B, 63, 971-989, doi:10.1111/j.1600-0889.2011.00580.x, 2011.

Jai Devi, J., Tripathi, S. N., Dey, S., Michael, M., and Gupta, T.: Probable linkage between aerosol and cloud in successive contrasting Monsoons (2008 and 2009), Ann. Geophys., submitted, 2014

Janjic, Z. I.: Nonsingular implementation of the Mellor-Yamada level 2.5 scheme in the NCEP meso model, NCEP Office Note No. 437, 2001.

Kulkarni, J. R., et al.: The Cloud Aerosol Interaction and Precipitation Enhancement Experiment (CAIPEEX): overview and preliminary results, Curr. Sci. India, 102, 413-425, 2012.

Kumar, R., Naja, M., Pfister, G. G., Barth, M. C., and Brasseur, G. P.: Simulations over South Asia using the Weather Research and Forecasting model with Chemistry (WRF-Chem): setup and meteorological evaluation, Geosci. Model Dev., 5, 321-343, doi:10.5194/gmd-5-3212012, 2012a.

Kumar, R., Naja, M., Pfister, G. G., Barth, M. C., Wiedinmyer, C., and Brasseur, G. P.: Simulations over South Asia using the Weather Research and Forecasting model with Chemistry (WRF-Chem): chemistry evaluation and initial results, Geosci. Model Dev., 5, 619-648, doi:10.5194/gmd-5-619-2012, 2012b.

Kumar, S., Devara, P. C. S., Dani, K. K., Sonbawne, S. M., and Saha, S. K.: Sun-sky radiometerderived column-integrated aerosol optical and physical properties over a tropical urban station during 2004-2009, J. Geophys. Res., 116, D10201, doi:10.1029/2010JD014944, 2011.

Lal, S., Naja, M., and Subbaraya, B. H.: Seasonal variations in surface ozone and its pre-

30 cursors over an urban site in India, Atmos. Environ., 34, 2713-2724, doi:10.1016/S13522310(99)00510-5, 2000. 
Lin, Y. L., Farley, R. D., and Orville, H. D.: Bulk parameterization of the snow field in a cloud model, J. Clim. Appl. Meteorol., 22, 1065-1092, doi:10.1175/15200450(1983)022<1065:BPOTSF>2.0.CO;2, 1983.

Lawrence, M. G. and Lelieveld, J.: Atmospheric pollutant outflow from southern Asia: a review,

$5 \quad$ Atmos. Chem. Phys., 10, 11017-11096, doi:10.5194/acp-10-11017-2010, 2010.

Mellor, G. L. and Yamada, T.: Development of a turbulence closure model for geophysical fluid problems, Rev. Geophys., 20, 851-875, doi:10.1029/RG020i004p00851, 1982.

Misenis, C. and Zhang, Y.: An examination of sensitivity of WRF/Chem predictions to physical parameterizations, horizontal grid spacing, and nesting options, Atmos. Res., 97, 315-334, doi:10.1016/j.atmosres.2010.04.005, 2010.

Misra, A., Tripathi, S. N., Kaul, D. S., and Welton, E. J.: Study of MPLNET-derived aerosol climatology over Kanpur, India, and validation of CALIPSO level 2 version 3 backscatter and extinction products, J. Atmos. Ocean. Tech., 29, 1285-1294, doi:10.1175/JTECH-D-1100162.1, 2012.

15 Mlawer, E. J., Taubman, S. J., Brown, P. D., Iacono, M. J., and Clough, S. A.: Radiative transfer for inhomogeneousatmosphere: RRTM, a validated correlated-k model for the longwave, J. Geophys. Res., 102, 16663-16682, doi:10.1029/97JD00237, 1997.

Moorthy, K. K., Satheesh, S. K., Babu, S. S., and Dutt, C. B. S.: Integrated campaign for aerosols, gases and radiation budget (ICARB): an overview, J. Earth Syst. Sci., 117, 243262, 2008.

Myhre, G.: Consistency between satellite-derived and modeled estimates of the direct aerosol effect, Science, 325, 187-190, doi:10.1126/science.1174461, 2009.

Myhre, G., Samset, B. H., Schulz, M., Balkanski, Y., Bauer, S., Berntsen, T. K., Bian, H., Bellouin, N., Chin, M., Diehl, T., Easter, R. C., Feichter, J., Ghan, S. J., Hauglustaine, D., Iversen, T., Kinne, S., Kirkevåg, A., Lamarque, J.-F., Lin, G., Liu, X., Lund, M. T., Luo, G., Ma, X., van Noije, T., Penner, J. E., Rasch, P. J., Ruiz, A., Seland, Ø., Skeie, R. B., Stier, P., Takemura, T., Tsigaridis, K., Wang, P., Wang, Z., Xu, L., Yu, H., Yu, F., Yoon, J.-H., Zhang, K., Zhang, $H_{\text {., }}$ and Zhou, C.: Radiative forcing of the direct aerosol effect from AeroCom Phase II simulations, Atmos. Chem. Phys., 13, 1853-1877, doi:10.5194/acp-13-1853-2013, 2013.

30 Nair, V. S., Solmon, F., Giorgi, F., Mariotti, L., Babu, S. S., and Moorthy, K. K.: Simulation of south Asian aerosols for regional climate studies, J. Geophys. Res., 117, D04209, doi:10.1029/2011JD016711, 2012.

Neter, J., Kutner, M., Wasserman, W., and Nachtsheim, C.: Applied Linear Statistical Models, 4th Edn., Irwin Series in Statistics, McGraw-Hill/Irwin, 509 pp., ISBN-13, 978-0256117363, 1996.

Niranjan, K., Babu, Y. R., Satyanarayana, G. V., and Thulasiraman, S.: Aerosol spectral optical depths and typical size distribution at a coastal urban location in India, Tellus B, 49, 439-446, 1997.

Ohara, T., Akimoto, H., Kurokawa, J., Horii, N., Yamaji, K., Yan, X., and Hayasaka, T.: An Asian emission inventory of anthropogenic emission sources for the period 1980-2020, Atmos. Chem. Phys., 7, 4419-4444, doi:10.5194/acp-7-4419-2007, 2007.

10 Pandithurai, G., Dipu, S., Dani, K. K., Tiwari, S., Bisht, D. S., Devara, P. C. S., and Pinker, R. T.: Aerosol radiative forcing during dust events over New Delhi, India, J. Geophys. Res., 113, D13209, doi:10.1029/2008JD009804, 2008.

Parameswaran, K., Rajan, R., Vijayakumar, G., Rajeev, K., Moorthy, K. K., Nair, P. R., and Satheesh, S. K.: Seasonal and long term variations of aerosol content in the atmospheric

15 mixing region at a tropical station on the Arabian sea-coast, J. Atmos. Sol.-Terr. Phys., 60, 17-25, 1998.

Purkait, N. N., De, S., Sen, S., and Chakrabarty, D. K.: Surface ozone and its precursors at two sites in the northeast coast of India, Indian J. Radio Space, 38, 86-97, 2009.

Qian, Y., Gustafson Jr., W. I., and Fast, J. D.: An investigation of the sub-grid variability of trace gases and aerosols for global climate modeling, Atmos. Chem. Phys., 10, 6917-6946, doi:10.5194/acp-10-6917-2010, 2010.

Ramachandran, S. and Cherian, R.: Regional and seasonal variations in aerosol optical characteristics and their frequency distributions over India during 2001-2005, J. Geophys. Res., 113, D08207, doi:10.1029/2007JD008560, 2008.

25 Ramanathan, V., Crutzen, P. J., Kiehl, J. T., and Rosenfeld, D.: Aerosol, climate and the hydrological cycle, Science, 294, 2119-24, 2001.

Reddy, M. S. and Venkataraman, C.: Inventory of aerosol and sulfur dioxide emissions from India: I. Fossil fuels combustion, Atmos. Environ., 36, 677-697, doi:10.1016/S13522310(01)00463-0, 2002.

30 Reddy, M. S., Boucher, O., Venkataraman, C., Verma, S., Leon, J. F., Bellouin, N., and Pham, M.: General circulation model estimates of aerosol transport and radiative forcing during the indian ocean experiment, J. Geophys. Res., 109, D16205, doi:10.1029/2004JD004557, 2004. 
Sadavarte, P., Madhavan, B. L., Venkataraman, C., Kulkarni, S., Carmichael, G. R., Adhikary, B., Cherian, R., D'Allura, A., Das, S., Gupta, T., Streets, D., Wei, C., and Zhang, Q.: Seasonal contrast in aerosol abundance and aerosol induced shortwave forcing over northern South Asia, Atmos. Environ., submitted, 2014.

5 Schell, B., Ackermann, I. J., Hass, H., Binkowski, F. S., and Ebel, A.: Modeling the formation of secondary organic aerosol within a comprehensive air quality modeling system, J. Geophys. Res., 106, 28275-28293, doi:10.1029/2001JD000384, 2001.

Shamjad, P. M., Tripathi, S. N., and Aggarwal, S. G.: Comparison of experimental and modeled absorption enhancement by Black Carbon $(B C)$ cored polydisperse aerosols under hygroscopic conditions, Environ. Sci. Technol., 46, 8082-8089, doi:10.1021/es300295v, 2012.

Shin, H. H. and Hong, S.-Y.: Intercomparison of planetary boundary layer parameterizations in the WRF model for a single day from CASES-99, Bound.-Lay. Meteorol., 139, 261-281, doi:10.1007/s10546-010-9583-z, 2011.

Sikka, D. R.: Developments in tropospheric aerosols studies in India, Indian J. Radio Space, 31, 391-403, 2002.

Singh, R. P., Dey, S., Tripathi, S. N., Tare, V., and Holben, B. N.: Variability of aerosol parameters over Kanpur, northern India, J. Geophys. Res., 109, D23206, doi:10.1029/2004JD004966, 2004.

Skeie, R. B., Berntsen, T. K., Myhre, G., Tanaka, K., Kvalevåg, M. M., and Hoyle, C. R.: An-

20 thropogenic radiative forcing time series from pre-industrial times until 2010, Atmos. Chem. Phys., 11, 11827-11857, doi:10.5194/acp-11-11827-2011, 2011.

Smirnov, A., O'Neill, N. T., Royer, A., Tarussov, A., and McArthur, B.: Aerosol optical depth over Canada and the link with synoptic air mass types, J. Geophys. Res., 101, 19299-19318, doi:10.1029/95JD02608, 1996.

25 Stier, P., Schutgens, N. A. J., Bellouin, N., Bian, H., Boucher, O., Chin, M., Ghan, S., Huneeus, N., Kinne, S., Lin, G., Ma, X., Myhre, G., Penner, J. E., Randles, C. A., Samset, B., Schulz, M., Takemura, T., Yu, F., Yu, H., and Zhou, C.: Host model uncertainties in aerosol radiative forcing estimates: results from the AeroCom Prescribed intercomparison study, Atmos. Chem. Phys., 13, 3245-3270, doi:10.5194/acp-13-3245-2013, 2013.

so Srivastava, A. K., Tiwari, S., Devara, P. C. S., Bisht, D. S., Srivastava, Manoj K., Tripathi, S. N., Goloub, P., and Holben, B. N.: Pre-monsoon aerosol characteristics over the Indo-Gangetic Basin: implications to climatic impact, Ann. Geophys., 29, 789-804, doi:10.5194/angeo-29789-2011, 2011a.

Srivastava, A. K., Tiwari, S., Bisht, D. S., China, P., Devara, S., Goloub, P., Li, Z., and Srivastava, M. K.: Aerosol characteristics during the coolest June month over New Delhi, northern India, Int. J. Remote Sens., 32, 8463-8483, doi:10.1080/01431161.2010.542196, 2011b.

Stockwell, W. R., Middleton, P., Chang, J. S., and Tang, X.: The second-generation regional acid deposition model chemical mechanism for regional air quality modeling, J. Geophys. Res., 95, 16343-16367, doi:10.1029/JD095iD10p16343, 1990.

Stockwell, R. W., Kirchner, F., Kuhn, M., and Seefeld, S.: A new mechanism for regional atmospheric chemistry modeling, J. Geophys. Res., 102, 25847-25879, 1997.

Tripathi, S. N., Dey, S., Chandel, A., Srivastava, S., Singh, R. P., and Holben, B. N.: Comparison of MODIS and AERONET derived aerosol optical depth over the Ganga Basin, India, Ann. Geophys., 23, 1093-1101, doi:10.5194/angeo-23-1093-2005, 2005.

Tripathi, S. N., Tare, V., Chinnam, N., Srivastava, A. K., Dey, S., Agarwal, A., Kishore, S., Lal, R. B., Manar, M., Kanwade, V. P., Chauhan, S. S. S., Sharma, M., Reddy, R. R., Rama Gopal, K., Narasimhulu, K., Reddy, L. S. S., Gupta, S., and Lal, S.: Measurements of atmospheric parameters during Indian Space Research Organization Geopshere Biosphere Programme land campaign II at a typical location in the Ganga basin: 1. Physical and optical properties, J. Geophys. Res., 111, D23209, doi:10.1029/2006JD007278, 2006.

Tuccella, P., Curci, G., Visconti, G., Bessagnet, B., Menut, L., and Park, R. J.: Modeling of gas and aerosol with WRF/Chem over Europe: evaluation and sensitivity study, J. Geophys. Res., 117, D03303, doi:10.1029/2011JD016302, 2012.

Venkataraman, C., Habib, G., Eiguren-Fernandez, A., Miguel, A. H., and Friedlander, S. K.: Residential biofuels in South Asia: carbonaceous aerosol emissions and climate impacts, Science, 307, 1424-1426, 2005.

Venkataraman, C., Habib, G., Kadamba, D., Shrivastava, M., Léon, J. F., Crouzille, B.,

25 Boucher, O., and Streets, D. G.: Emissions from open biomass burning in India: integrating the inventory approach with high-resolution Moderate Resolution Imaging Spectroradiometer (MODIS) active-fire and land cover data, Global Biogeochem. Cy., 20, GB2013, doi:10.1029/2005GB002547, 2006.

Verma, S., Boucher, O., Venkataraman, C., Reddy, M. S., Müller, D., Chazette, P., and $30 \quad$ Crouzille, B.: Aerosol lofting from sea breeze during the Indian Ocean Experiment, J. Geophys. Res., 111, D07208, doi:10.1029/2005JD005953, 2006. 
Verma, S., Venkataraman, C., and Boucher, O.: Origin of surface and columnar Indian ocean experiment (INDOEX) aerosols using source- and region-tagged emissions transport in a general circulation model, J. Geophys. Res., 113, D24211, doi:10.1029/2007JD009538, 2008.

Verma, S., Venkataraman, C., and Boucher, O.: Attribution of aerosol radiative forcing over India

5 during the winter monsoon to emissions from source categories and geographical regions, Atmos. Environ., 45, 4398-4407, doi:10.1016/j.atmosenv.2011.05.048, 2011.

Welton, E. J., Campbell, J. R., Spinhirne, J. D., and Scott, V. S. III: Global monitoring of clouds and aerosols using a network of micropulse lidar systems, in: Lidar Remote Sensing for Industry and Environment Monitoring, edited by: Singh, U. N., SPIE Proceedings, Vol. 4153, International Society for Optical Engineering, 151-158, doi:10.1117/12.417040, 2011.

Wild, M.: Global dimming and brightening: a review, J. Geophys. Res., 114, D00D16, doi:10.1029/2008JD011470, 2009.

Wild, O., Zhu, X., and Prather, M. J.: Fast-J: accurate simulation of in- and belowcloud photolysis in tropospheric chemical models, J. Atmos. Chem., 37, 245-282, doi:10.1023/A:1006415919030, 2000.

Table 1. Meteorological and chemical process options used in the WRF-chem model.

\begin{tabular}{|c|c|}
\hline Atmospheric Process & Model Option \\
\hline \multicolumn{2}{|l|}{ Meteorology } \\
\hline Longwave radiation & RRTM (Mlawer et al., 1997) \\
\hline Shortwave radiation & Goddard (Chou et al., 1998) \\
\hline Surface layer & Monin-Obukhov \\
\hline Land surface & Noah (Chen and Dudhia, 2001) \\
\hline Boundary layer & Mellor-Yamada-Janic (Mellor and Yamada, 1982; Janjic, 2001) \\
\hline Cumulus Parameterization & Grell-Devenyi (Grell and Devenyi, 2002) \\
\hline Cloud microphysics & Lin (Lin et al., 1983) \\
\hline \multicolumn{2}{|l|}{ Chemistry } \\
\hline Gas-Phase chemistry & RADM2 (Stockwell et al., 1990) \\
\hline Aerosol processes & MADE/SORGAM (Ackermann et al., 1998; Schell et al., 2001) \\
\hline Photolysis & Fast-J (Wild et al., 2000) \\
\hline
\end{tabular}


Table 2. The mean bias, RMSE and correlation coefficient of the trace gases at Kanpur for the period May-June 2010.

\begin{tabular}{lrrr}
\hline & $\mathrm{O}_{3}$ & $\mathrm{CO}$ & $\mathrm{SO}_{2}$ \\
\hline $\mathrm{MB}$ & -12.27 & 0.15 & -1.45 \\
$\mathrm{RMSE}$ & 22.54 & 0.30 & 3.55 \\
$R^{2}$ & 0.13 & 0.02 & 0.30 \\
\hline
\end{tabular}

463

Table 3. Aerosol Optical Depth at different locations during May-June 2008, 2009 and 2010.

\begin{tabular}{lllllll}
\hline & \multicolumn{2}{c}{2008} & \multicolumn{2}{c}{ Aerosol optical depth } & & 2010 \\
Location & Simulated & Observed & Simulated & Observed & Simulated & Observed \\
\hline Kanpur & $0.42 \pm 0.19$ & $0.66 \pm 0.20$ & $0.42 \pm 0.34$ & $0.67 \pm 0.32$ & $0.44 \pm 0.32$ & $0.73 \pm 0.63$ \\
Nainital & $0.34 \pm 0.20$ & $0.49 \pm 0.26$ & $0.32 \pm 0.20$ & $0.34 \pm 0.18$ & $0.33 \pm 0.40$ & $0.42 \pm 0.32$ \\
Jaipur & & & $0.47 \pm 0.38$ & $0.57 \pm 0.34$ & $0.48 \pm 0.56$ & $0.57 \pm 0.29$ \\
Gandhi College & & & $0.36 \pm 0.23$ & $0.72 \pm 0.35$ & & \\
Kharagpur & & & $0.36 \pm 0.21$ & $0.77 \pm 0.43$ & & \\
New Delhi & & & $0.45 \pm 0.38$ & $0.66 \pm 0.18$ & & \\
Bareilly & $0.40 \pm 0.22$ & $0.70 \pm 0.38$ & & & & \\
Pantnagar & $0.37 \pm 0.24$ & $0.66 \pm 0.27$ & $0.35 \pm 0.26$ & $0.69 \pm 0.35$ & & \\
Pune & $0.20 \pm 0.21$ & $0.25 \pm 0.09$ & $0.25 \pm 0.26$ & $0.36 \pm 0.13$ & $0.23 \pm 0.11$ & $0.33 \pm 0.13$ \\
\hline
\end{tabular}


Table 4. The mean bias, RMSE and correlation coefficient of the Aerosol Optical Depth at different locations during May-June 2008, 2009 and 2010.

\begin{tabular}{lrrr}
\hline Location & MB & RMSE & $R^{2}$ \\
\hline Kanpur & 0.23 & 0.25 & -0.08 \\
Nainital & 0.03 & 0.15 & -0.02 \\
Jaipur & 0.10 & 0.24 & -0.08 \\
Gandhi College & 0.36 & 0.24 & -0.19 \\
Kharagpur & 0.38 & 0.20 & 0.27 \\
New Delhi & 0.22 & 0.13 & 0.26 \\
Bareilly & 0.31 & 0.23 & -0.12 \\
Pantnagar & 0.32 & 0.21 & -0.14 \\
Pune & 0.11 & 0.14 & 0.01 \\
\hline
\end{tabular}

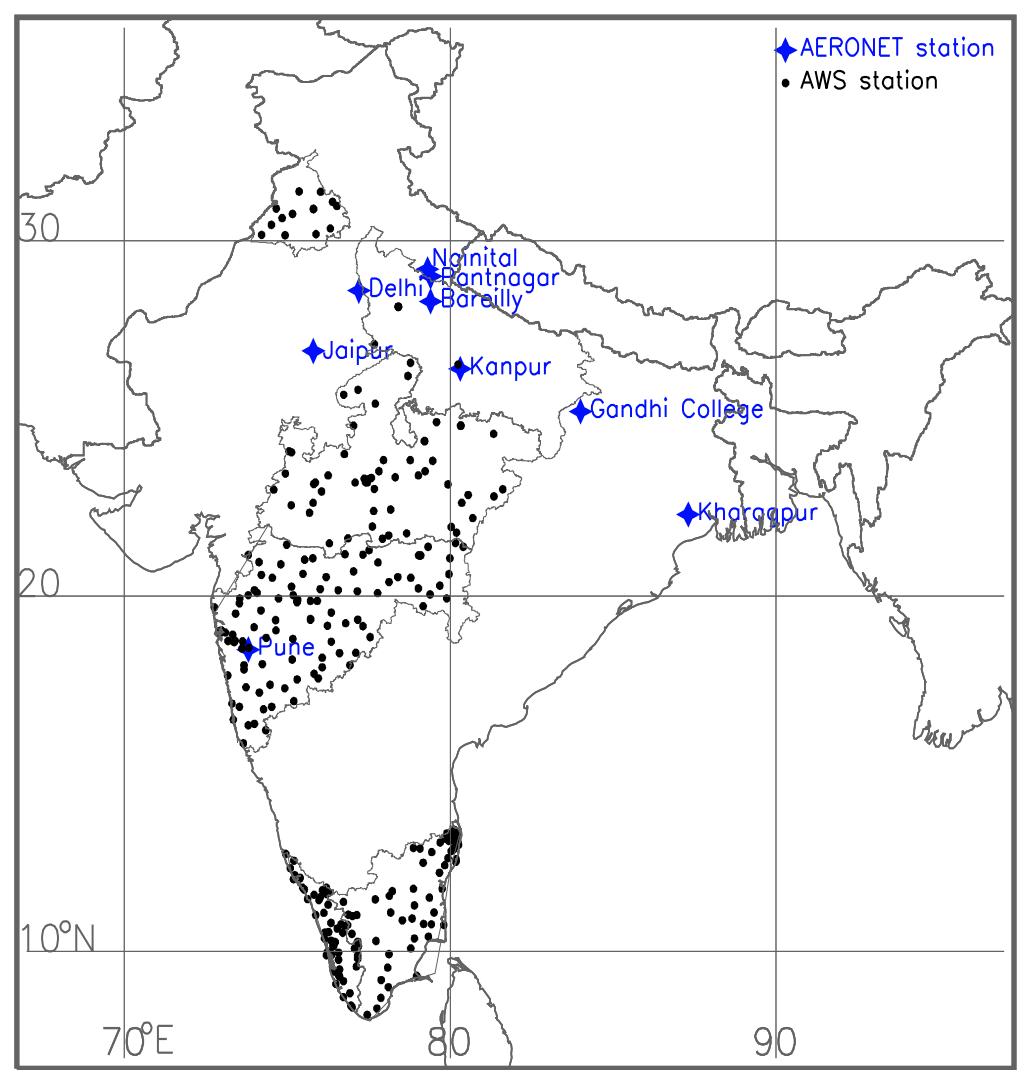

Fig. 1. Domain of study. 

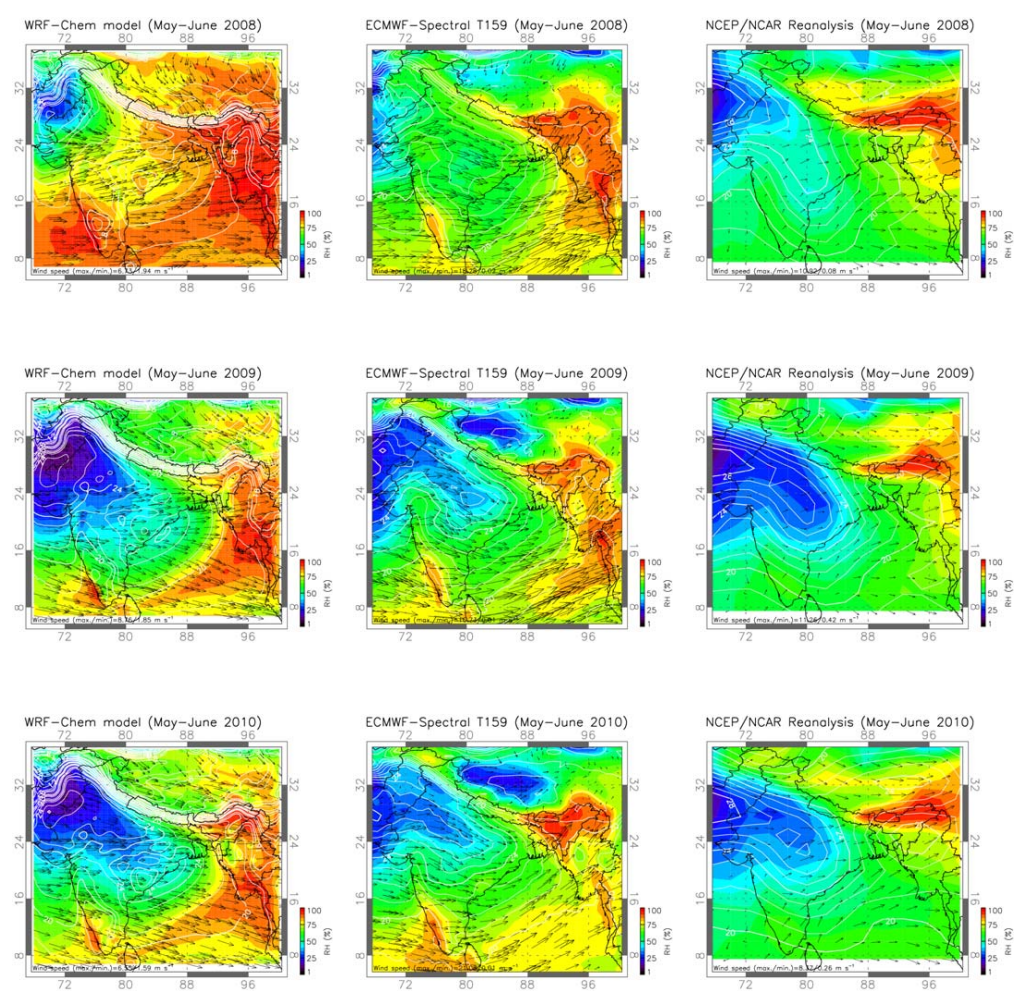

Fig. 2. Meteorological parameters at $850 \mathrm{hPa}$ averaged for May and June. $\mathrm{RH}$ in color, temperature as contours, and wind direction as arrows. (a) Simulated using WRF-chem for 2010, (b) reanalysis data from ECMWF for 2010, (c) simulated for 2009, (d) reanalysis for 2009, (e) simulated for 2008, (d) reanalysis for 2008.
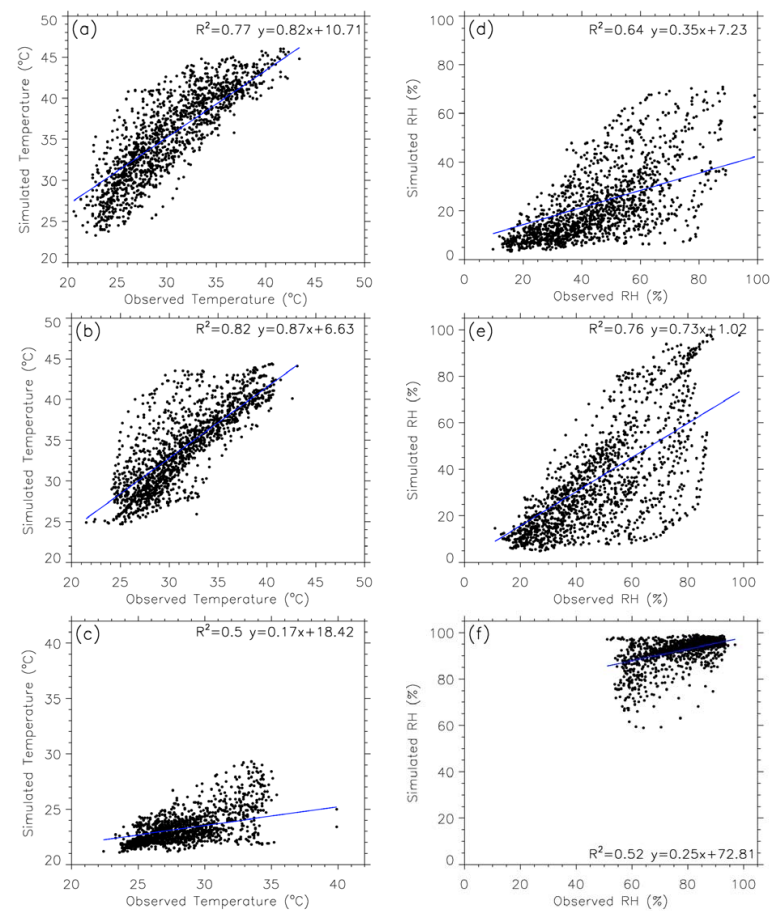

Fig. 3. Scatter plot of the hourly data of $2 \mathrm{~m}$ temperature and RH for May-June 2010; (a) temperature for IGP, (b) temperature for central India, (c) temperature for coastal India, (d) $\mathrm{RH}$ for IGP, (e) RH for central India, (f) RH for coastal India. Simulated=WRF-Chem and Observed $=$ MOSDAC. 


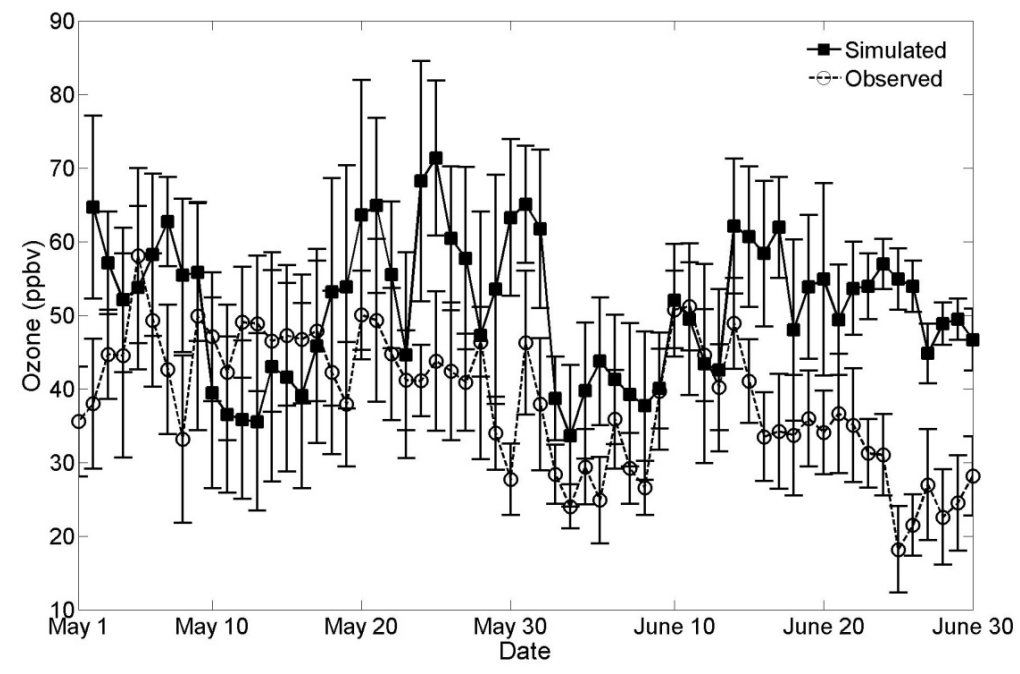

Fig. 4. Daily average of $\mathrm{O}_{3}$ at Kanpur for the period May-June 2010.

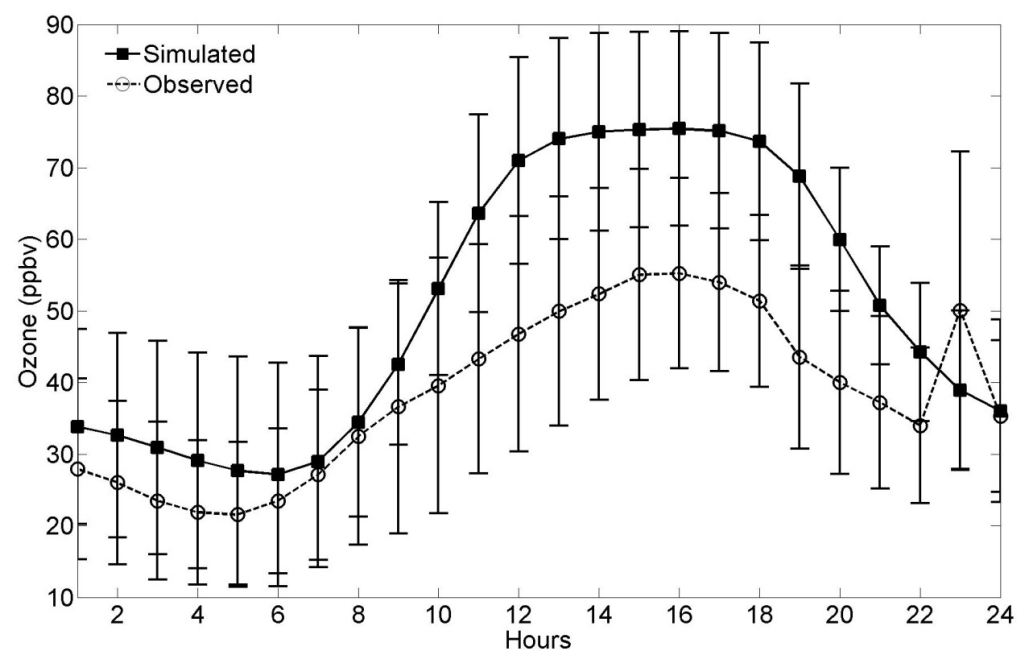

Fig. 5. Diurnal variation of $\mathrm{O}_{3}$ at Kanpur for the period May-June 2010. 


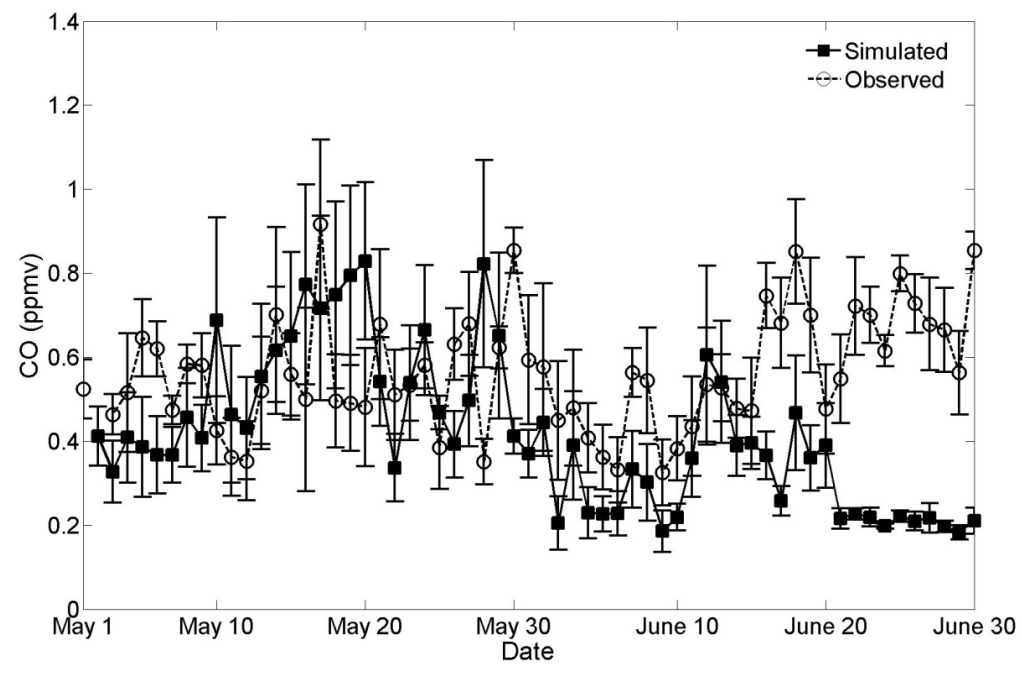

Fig. 6. Daily average of CO at Kanpur for the period May-June 2010.

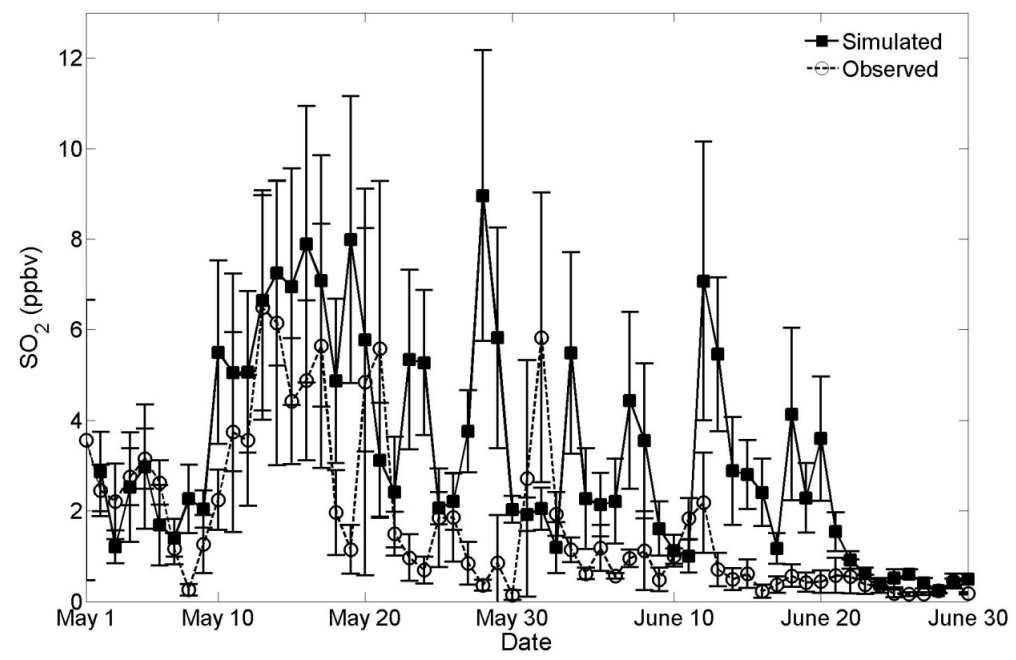

Fig. 7. Daily average of $\mathrm{SO}_{2}$ at Kanpur for the period May-June 2010. 


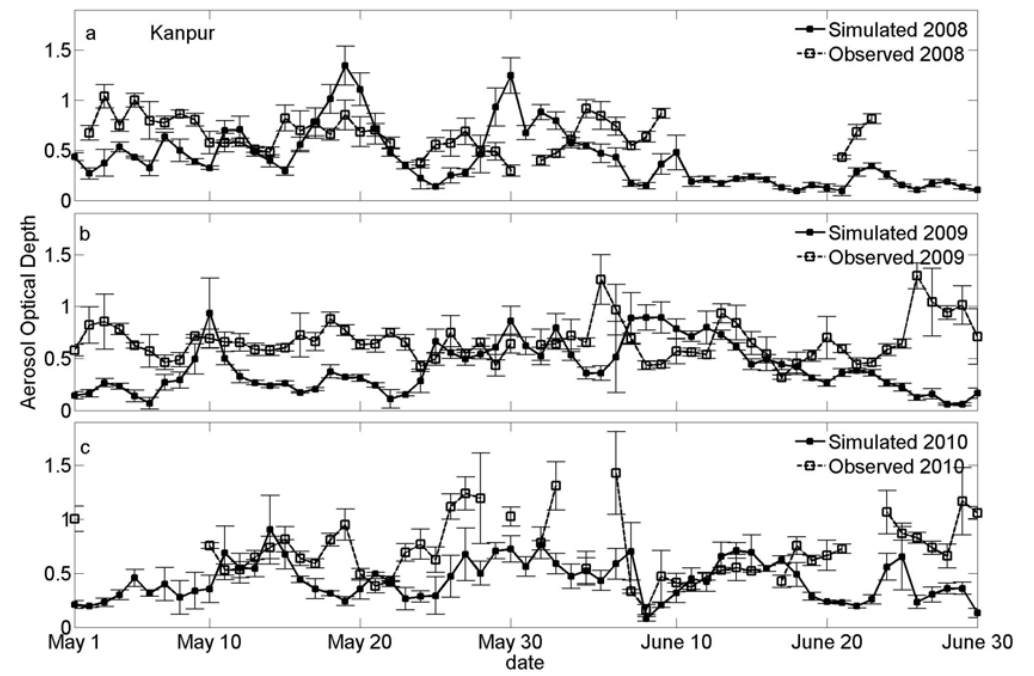

Fig. 8. Aerosol optical depth at Kanpur for the period May-June 2008, 2009 and 2010.

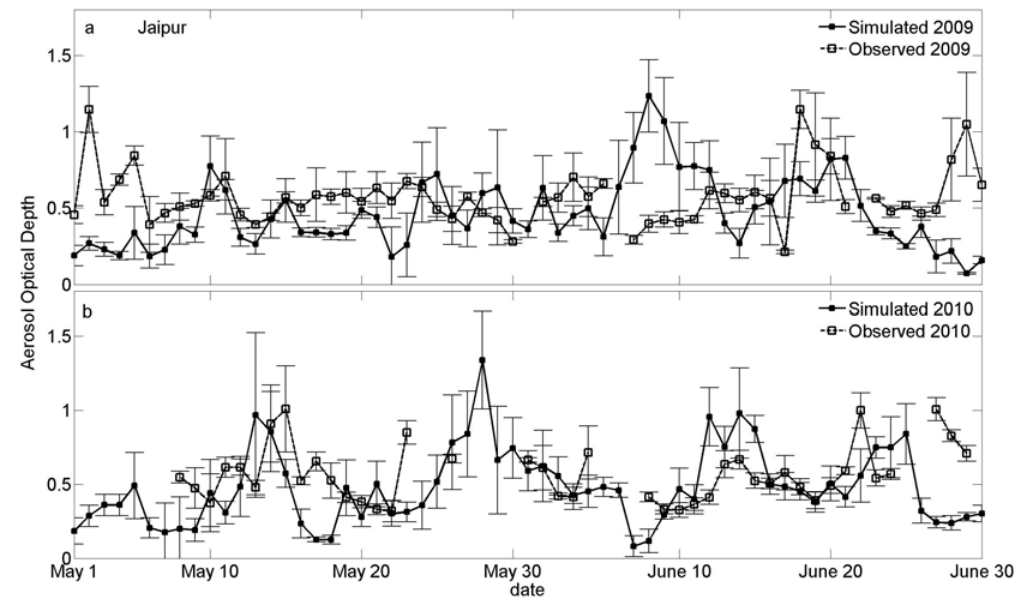

Fig. 9. Daily aerosol Optical depth at Jaipur for the period May-June 2009, and 2010. 


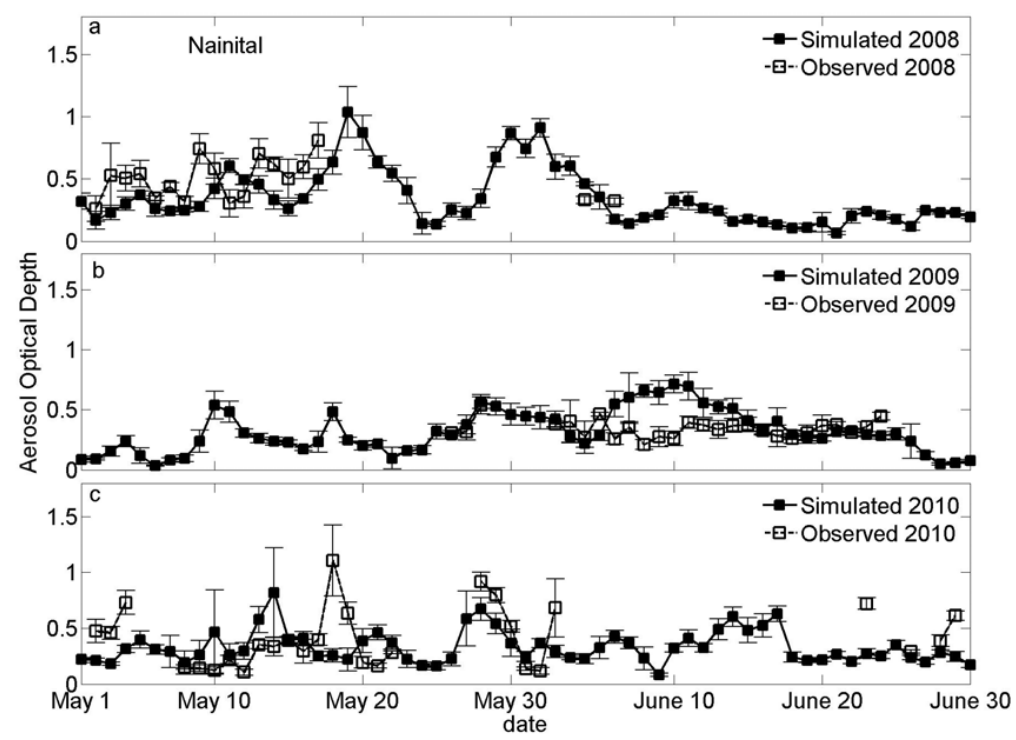

Fig. 10. Daily aerosol Optical depth at Nainital for the period May-June 2008, 2009 and 2010.

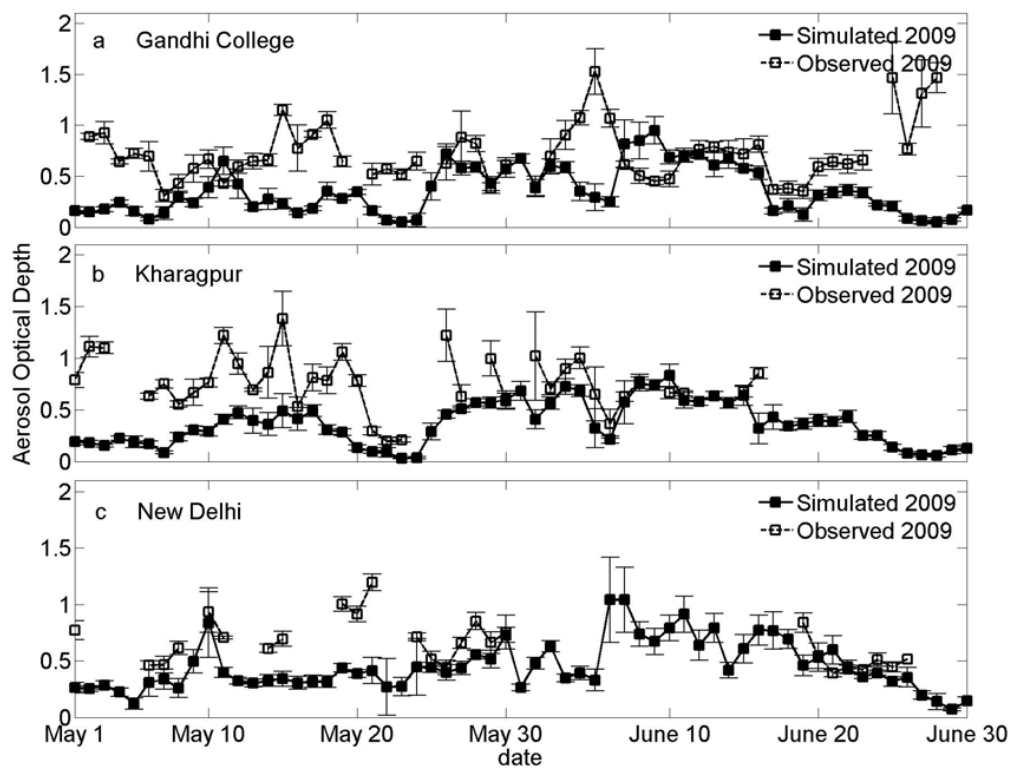

Fig. 11. Daily aerosol Optical depth at Gandhi College, Kharagpur and New Delhi for the period May-June 2009. 


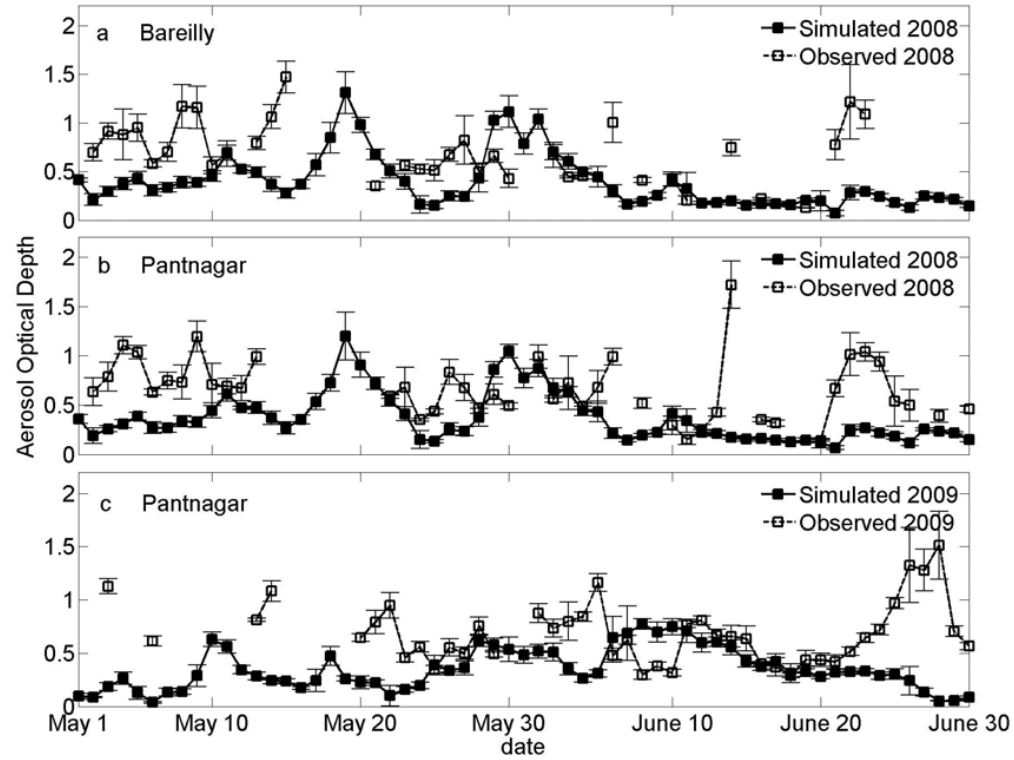

Fig. 12. Daily aerosol Optical depth at Bareilly and Pantnagar for the period May-June 2008, and 2009.

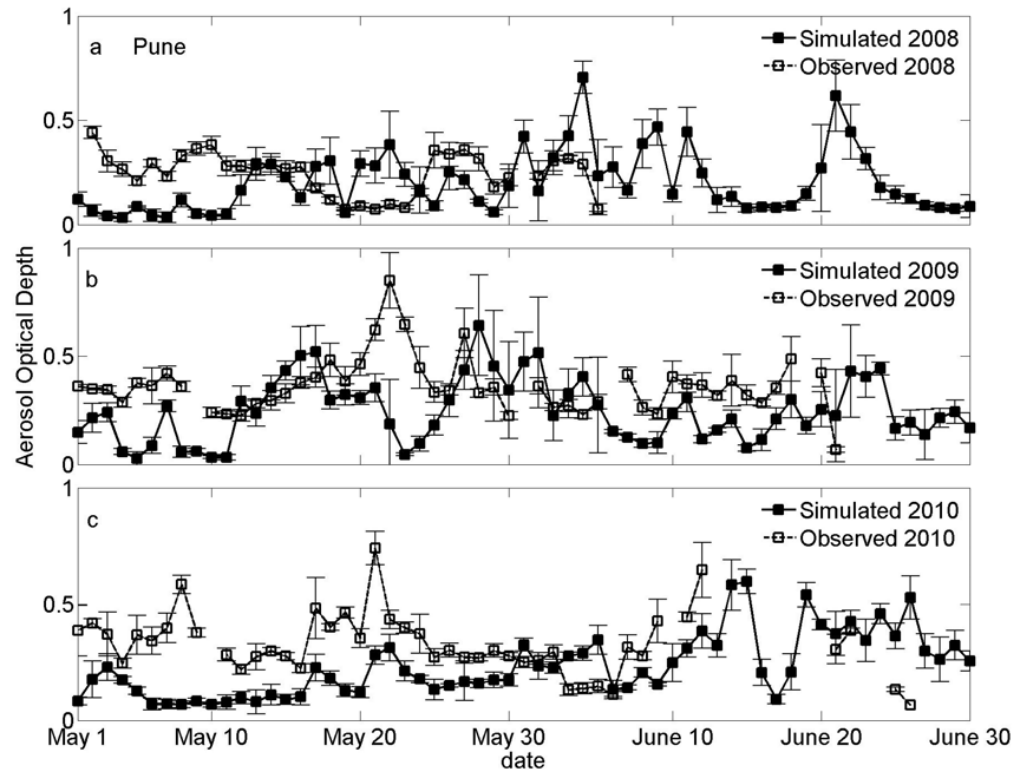

Fig. 13. Daily aerosol Optical depth at Pune for the period May-June 2008, 2009 and 2010. 

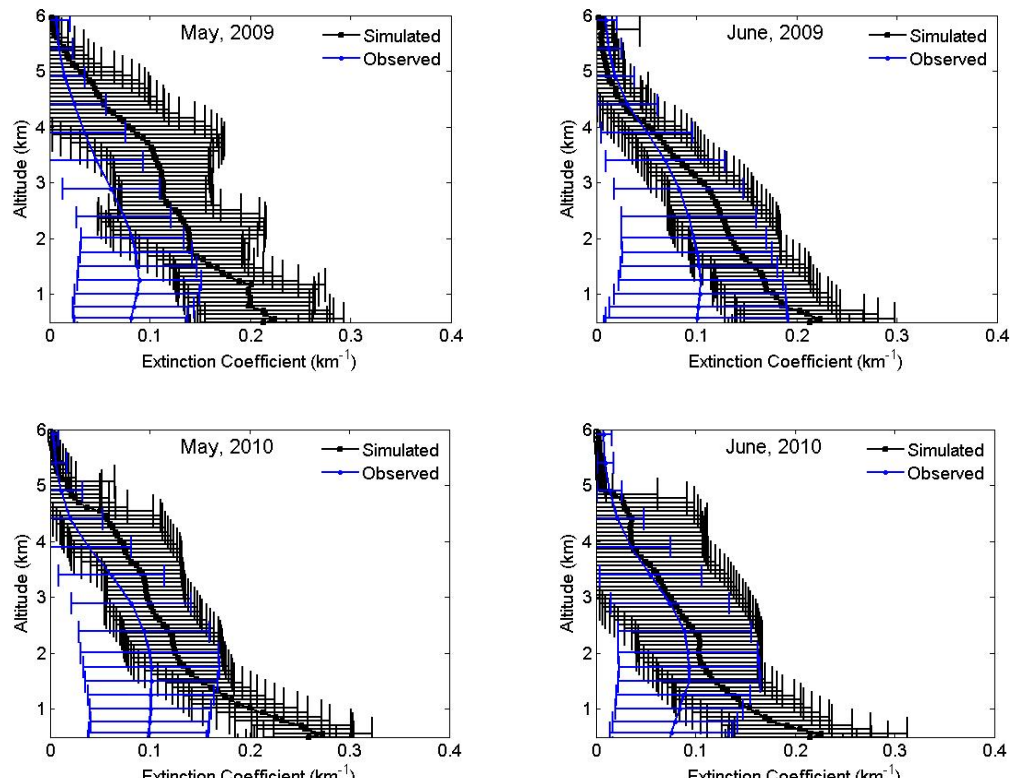

Fig. 14. Comparison between simulated and observed extinction coefficient at Kanpur averaged for a month (a) May 2009, (b) June 2009, (c) May 2010, and (d) June 2010. The error bars indicate one standard deviation.

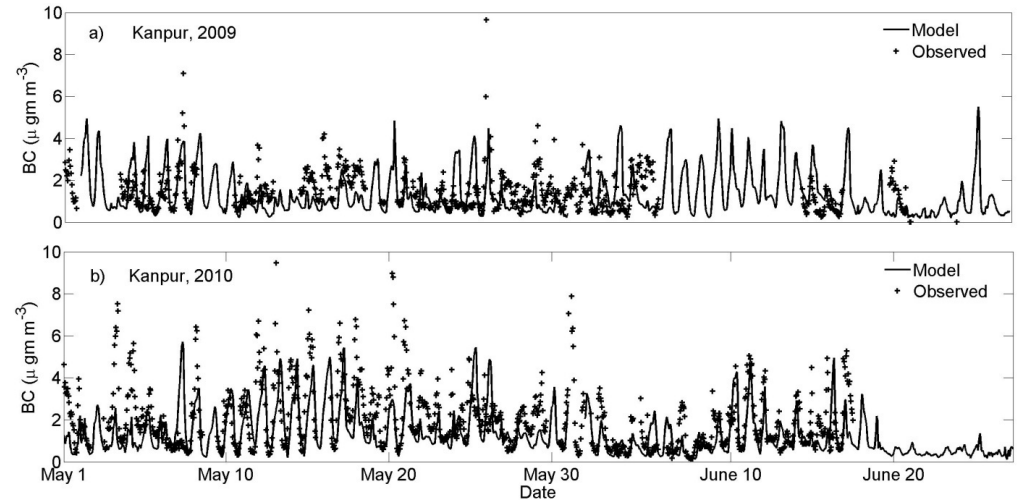

Fig. 15. BC mass concentration at Kanpur for the period (a) May-June 2009 and (b) 2010. 

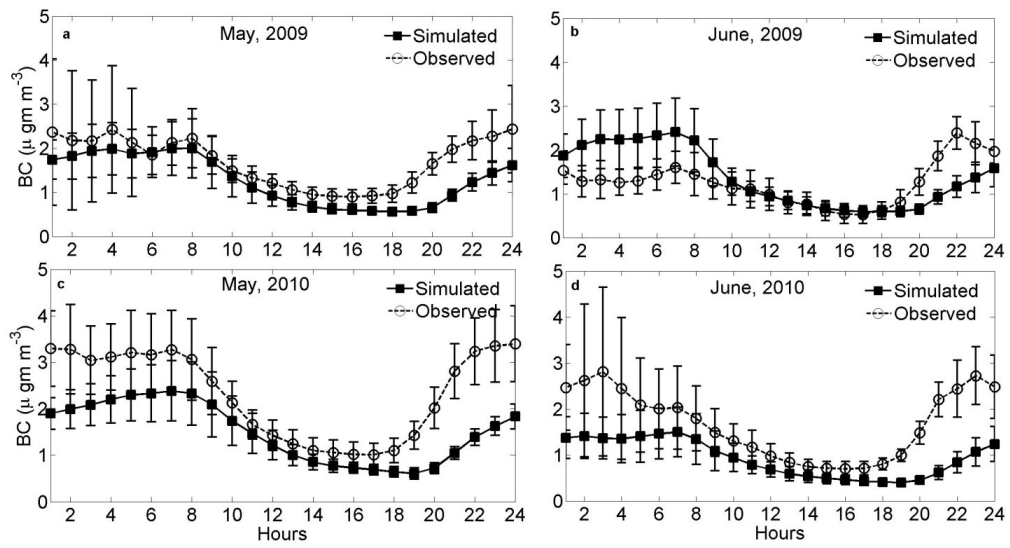

Fig. 16. Diurnal variation of BC over Kanpur averaged for a month (a) May 2009, (b) June 2009, (c) May 2010, and (d) June 2010.
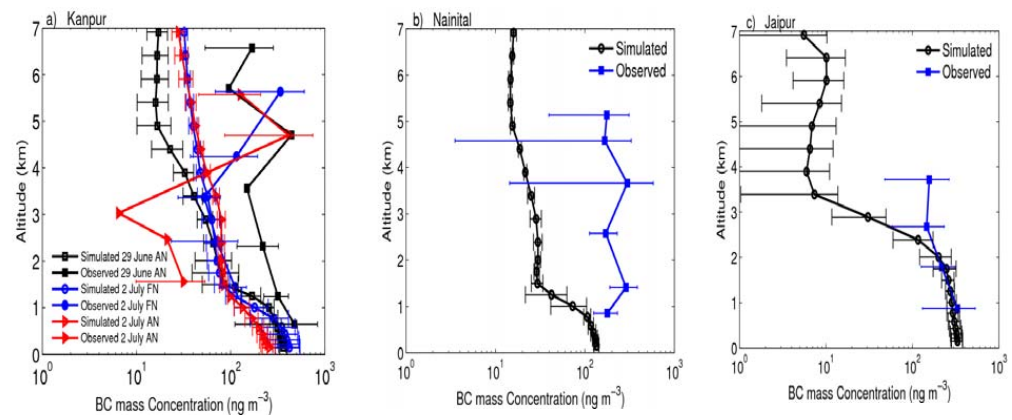

Fig. 17. Vertical profile of $B C$ at (a) Kanpur for 29 June 2009 averaged for 13:00 to 18:00 LT, 2 July 2009 averaged for 11:00 to 13:00 LT, and 2 July 2009 averaged for 13:00 to 16:00 LT; (b) Nainital for 29 June 2009 averaged for 10:00 to 13:00 LT; (c) Jaipur for 3 July 2009 averaged for 13:00 to 15:00 LT. The error bars indicate one standard deviation value. 